\title{
How do plants defend themselves against pathogens-Biochemical mechanisms and genetic interventions
}

\author{
Simardeep Kaur ${ }^{1} \cdot$ Mahesh Kumar Samota $^{2} \cdot$ Manoj Choudhary ${ }^{3,4}{ }^{\cdot} \cdot$ \\ Mukesh Choudhary $^{5,6} \cdot$ Abhay K. Pandey ${ }^{7}$ Anshu Sharma ${ }^{8} \cdot$ Julie Thakur $^{9}$
}

Received: 23 July 2021/Revised: 4 February 2022 / Accepted: 6 February 2022/Published online: 7 March 2022

(C) The Author(s) 2022

\begin{abstract}
In agro-ecosystem, plant pathogens hamper food quality, crop yield, and global food security. Manipulation of naturally occurring defense mechanisms in host plants is an effective and sustainable approach for plant disease management. Various natural compounds, ranging from cell wall components to metabolic enzymes have been reported to protect plants from infection by pathogens and hence provide specific resistance to hosts against pathogens, termed as induced resistance. It involves various biochemical components, that play an important role in molecular and cellular signaling events occurring either before (elicitation) or after pathogen infection. The induction of reactive oxygen species, activation of defensive machinery of plants comprising of
\end{abstract}

Manoj Choudhary

manoj04444@gmail.com

1 Division of Biochemistry, ICAR-Indian Agricultural Research Institute, New Delhi, India

2 HCP Division, ICAR-CIPHET, Abohar 152116, Punjab, India

3 ICAR-National Research Center for Integrated Pest Management, New Delhi, India

4 Department of Plant Pathology, University of Florida, Gainesville, United States

5 School of Agriculture and Environment, The University of Western Australia, Perth, Australia

6 ICAR-Indian Institute of Maize Research, PAU Campus, Ludhiana, India

7 Department of Mycology and Microbiology, Tea Research Association-North Bengal Regional R \& D Center, Nagrakata, West Bengal 735225, India

8 Department of FST, Dr. YS Parmar UHF Nauni, Solan, India

9 Department of Botany, Bhaskaracharya College of Applied Sciences, University of Delhi, Delhi, India enzymatic and non-enzymatic antioxidative components, secondary metabolites, pathogenesis-related protein expression (e.g. chitinases and glucanases), phytoalexin production, modification in cell wall composition, melatonin production, carotenoids accumulation, and altered activity of polyamines are major induced changes in host plants during pathogen infection. Hence, the altered concentration of biochemical components in host plants restricts disease development. Such biochemical or metabolic markers can be harnessed for the development of "pathogen-proof" plants. Effective utilization of the key metabolites-based metabolic markers can pave the path for candidate gene identification. This present review discusses the valuable information for understanding the biochemical response mechanism of plants to cope with pathogens and genomics-metabolomics-based sustainable development of pathogen proof cultivars along with knowledge gaps and future perspectives to enhance sustainable agricultural production.

Keywords Induced resistance - Antioxidative components · Phytoalexin · Melatonin · PR proteins . Polyamines

\section{Introduction}

The biotic stress constantly affects the agro-ecosystem which includes viruses, mycoplasmas, bacteria and fungi which directly alter the soil health and fertility and productivity of crops. Pathogens disturb the physiological and metabolic processes and pathways in plants resulting in loss of yield and quality in plants (Kumar and Verma 2018). Among all the processes, components of biochemical pathways play a vital part in safeguarding plants against pathogens. In general, when there is no stress, the plants 
exhibit optimal growth and development by using the available oxygen. However, during stress like pathogen attack, usage of oxygen results in the production of reactive oxygen species (ROS) in plant tissues (Singla et al. 2019), which in turn causes photo-oxidative damage to biomolecules and the internal cellular structures (Xie et al. 2016; Mittler 2017). The plants respond to such interaction of microbes by inducing a plethora of biochemical changes associated with stress signaling and thus activating their defense pathways. The induced defense mechanism includes various non-enzymatic components comprising phenolic compounds, flavonoids, lignins and enzymes for phenol metabolism like phenylalanine ammonia-lyase (PAL), polyphenol oxidase (PPO) and antioxidant enzymes like superoxide dismutase (SOD), catalase (CAT), peroxidases (POX) and glutathione reductase (GR) (Debona et al. 2012; Akter et al. 2015), accumulation of tannins and phytoalexins. Besides, changes in cell wall composition act as a passive structural fence against pathogen attack. Das and Roychoudhury (2014a, b) reported that carotenoids and lipophilic organic compounds also serve as a defense mechanism for the detoxification of several types of ROS. Another defensive compound such as phytoalexins is also produced in host plants as secondary metabolites by the hypersensitive response. During the pathogen infection, phytoalexins accumulate at the infection site and prevent the fungal growth and also of other pathogens in-vivo and thus, considered as an important plant-defensive compound against many necrotrophic and biotrophic pathogens (Bizuneh 2020). Apart from this, polyamines (PAs) also play a key function in the plant's cellular metabolism and hence act as a protective barrier to pathogens by alteration of their activities (Hussain et al. 2011). Hence, the plants are well equipped with natural biochemical compounds to cope with the plant pathogens. Therefore, the present review is aimed to deliver a synthesis of the literature that discusses the function of various plant biochemical components in selfdefense against pathogens. Furthermore, we also aimed to discuss the plant defense systems against pathogens through elaborating on the production of ROS, alteration in metabolites, antimicrobial compounds and their role in defense and modification of cell wall composition. Besides, the use of metabolic/biochemical markers for the development of pathogen-resistant cultivars has also been discussed.

\section{Plant disease resistance genes}

During the plant-pathogen interaction, the plant releases several types of elicitors. These elicitors are recognized by plant resistance genes and trigger various biochemical and physiological changes in plants. Plant pathogens, pathogenassociated molecular patterns (PAMPs) are recognized by pattern recognition receptors (PRRs) and damage-associated molecular patterns (DAMPs) by wall-associated kinases (WAKs) within the cell membrane. Recognition and signaling cascade lead to pathogen triggered immunity (PTI). Other elicitors, generally called effectors are intercepted nucleotide-binding domains and leucine-rich repeats (NLRs) and this kind of recognition by R gene and defense response is called effector-triggered immunity (ETI) (Jones and Dangl 2006). PTI and ETI are interconnected and complement each other defense pathways instead of the earlier "Zig-Zag" way (Ngou et al. 2021). PRRs, WAKs, and NLRs mediated interconnected signaling cascades regulated Mitogen-activated protein kinases (MAPKs), ubiquitin, transcription factors (TFs), calcium, hormones, G-proteins expression in the plant (Gururani et al. 2012; Meng and Zhang 2013; Andersen et al., 2018). This leads to various defense responses that reduce pathogen spread; cell wall modification, closure of stomata, production of ROS, hypersensitive response, or the production of various anti-pathogen proteins and compounds (e.g., protease inhibitors, chitinases, defensins, and phytoalexins) (van Loon et al. 2006).

\section{Plant defense system against plant pathogens}

In natural habitats, plant defense systems serve a pivotal role in safeguarding plants against pathogens and in nutrient mobilization (Miller et al. 2010). In addition to self-defense of plants, useful microbes and plant growthpromoting rhizobacteria also activate the defense mechanism via two different pathways, systemic acquired resistance (SAR) and induce systematic resistance (ISR). The ISR may be strengthened through beneficial microorganisms, whereas SAR implies an altered gene expression at molecular levels and is related to PR proteins. Nawrocka and Małolepsza (2013) reported that both ISR and SAR, have different gene expression and induction mechanisms that depend on the regulatory pathway. Under biotic stress, beneficial microbes stimulate SAR which includes an accumulation of PR protein and salicylic acid (SA), however, ISR depends on jasmonate and ethylene regulated pathways (Salas-Marina et al. 2011). The biochemical mechanism of self-defense in plants (induced by themselves) against pathogens has been covered under the following sections.

\section{Production of ROS and its role in protection mechanism}

ROS production is significant to carry out a hypersensitive response for host defense. The balance between synthesis and removal of ROS is directly interrupted by biotic or 
abiotic stress (Mittler 2017). A common consequence in the cell under any stress is the production of ROS, viz., hydrogen peroxide $\left(\mathrm{H}_{2} \mathrm{O}_{2}\right)$, superoxide anion radical $\left(\mathrm{O}_{2}{ }^{\bullet-}\right)$, singlet oxygen $\left({ }^{1} \mathrm{O}_{2}\right)$ and hydroxyl radical $\left({ }^{\bullet} \mathrm{OH}\right)$ that could lead to extreme oxidative loss to plant tissues. In higher plants, lower levels of ROS have been found to regulate differentiation, redox homeostasis, stress signaling and systemic responses, however, elevated levels of ROS harm cellular components through protein damage, lipid peroxidation and membrane destruction (Das and Roychoudhury 2014a, b). Thus, high ROS affects normal cellular functioning (Asthir et al. 2010). Under stress conditions, plants send signals to alter their metabolism for the synthesis/activation of defensive genes in affected plant parts (Gill et al. 2019).

During stressful conditions, the ROS production rate dramatically increases in plants' mitochondria, chloroplast, endoplasmic reticulum, apoplast, peroxisomes, plasma membrane and cellular walls (Sharma et al. 2012; Mittler 2017). ROS affects the lipids, proteins as well as DNA in plant cells. During stressful conditions, lipid peroxidation increases significantly through the formation of lipid radicals (Meo et al. 2016). ROS also causes oxidation and modifications of the proteins directly or indirectly. Direct changes include nitrosylation, carboxylation, the formation of disulfide bonds and glutathionylation. Interaction of lipid peroxidation products with protein may also lead to indirect changes. Various amino acids like proline, lysine, threonine, arginine, methionine and cysteine are highly susceptible to ROS attack (Petrov et al. 2015). ROS also causes damage to DNA at multiple sites that include changes in nitrogenous bases, breakage of DNA strands, oxidation of deoxyribose sugar, etc. If the cross-linking between DNA and protein is not repaired in time it is very harmful and deadly to the plant (Popracet al. 2017). ROS détoxifications are carried out when plant cells, enzymes and redox metabolites function synergistically to protect themselves from adverse effects. Oxidative stress tolerance is an integrated mechanism associated with the changes in antioxidative/defensive enzymes, free radical scavenging activities, non-enzymatic antioxidants, osmolytes and signaling molecules (Caverzan et al. 2016). The induced defense is facilitated via defensive enzymes i.e., CAT, SOD, POX, PAL, PPO, ascorbate peroxidase (APX) and tyrosine ammonia-lyase (TAL) along with secondary metabolites such as phenols and condensed tannins and also through the utilization of $\mathrm{H}_{2} \mathrm{O}_{2}$ and malondialdehyde (MDA) (Bhaduri and Fulekar 2012). During various environmental stresses or pathogenic attacks, the first line of defense is formed by SOD against ROS-induced loss in barley (Torun et al. 2019).
Major antioxidative enzymes that perform a significant role in plant-defense mechanism are discussed in Table 1 and Fig. 1.

\section{Structural modifications in host plants}

The plant cell wall is the primary target site of infection by the pathogen. Over a million years of co-evolution, plants have evolved a multilayered defense mechanism against microbes, of which the cell wall is a vital component. Microbes establish a pathogenic relationship with host plants by avoiding the plant cell wall which requires suitable host recognition tactics followed by the appropriate infection structures and/or chemical exudates formation (Turra et al. 2015). The microbes that fail to evolve suitable tactics to bypass the cell wall of a host plant remain as non-pathogens or non-adapted pathogens. In the case of pathogenic microbes, with the ability to overcome preformed barriers, the host plant uses the cell wall as a defense barrier. Some of the mechanisms include:

\section{Release of elicitors}

Boller and Felix (2009) reported the release of oligosaccharide elicitors during infection from the cell wall of a host plant DAMPs or of a pathogen PAMPs as a part of the process of degradation. Plants recognize these elicitors with a help of immune receptors present on the plasma membrane which eventually trigger signaling cascades to activate various DAMP or PAMP-triggered immunity defense mechanisms, these are also known as Defense Triggered Immunity (DTI) or PTI, respectively (Jones and Dangl 2006). One of the common defense responses among DTI or PTI is the cell wall reinforcement to develop more resistance to physical pressure and/or hydrolytic enzyme produced by the pathogens (Malinovsky et al. 2014). Moerschbacher and Mendgen (2012) reported that the reinforcement of the cell wall process may take place by various means depending upon the type of interaction with elicitors such as cross-linking and rearrangement of preexisting cell wall components, the inclusion of cross-linked polymerized materials to the existing cell wall and local cell wall components deposition at the site of infection. For example, the elicitors induce thickening of outer layer parenchyma cells and produce amorphous, fibrillar material to trap the bacteria (Keane 2012). In contrast to bacteria, various defensive substances like callose, hydroxyproline amino acid-rich glycoproteins (such as an extension), phenolic compounds (also lignin as well as suberin) and mineral elements (e.g., calcium and silicon) are produced and deposited into the cell wall to safeguard against fungus attack (Deepak et al. 2010). 
Table 1 Description of defensive enzymatic machinery of plants against pathogens

\begin{tabular}{|c|c|c|c|c|c|}
\hline $\begin{array}{l}\text { Name of } \\
\text { enzyme }\end{array}$ & Description & Isoforms/types & Function & Reaction catalyzed & References \\
\hline $\begin{array}{l}\text { Superoxide } \\
\text { dismutase } \\
\text { (SOD) }\end{array}$ & $\begin{array}{l}\text { Family of metalloenzymes present in all } \\
\text { organisms. During various } \\
\text { environmental stresses or pathogenic } \\
\text { attacks, SOD forms the first line of } \\
\text { defense against ROS induced damages }\end{array}$ & $\begin{array}{l}\text { 1. Mn-SOD (localized in } \\
\text { mitochondria) } \\
\text { 2. Fe-SOD (present in } \\
\text { chloroplasts) } \\
\text { 3. Cu/Zn-SOD (residing } \\
\text { in cytosol, } \\
\text { peroxisomes, and } \\
\text { chloroplasts) } \\
\text { 4. Increased activity of } \\
\text { SOD provides } \\
\text { resistance against } \\
\text { Alternaria solani in } \\
\text { tomato }\end{array}$ & $\begin{array}{l}\text { Removal of } \mathrm{O}_{2}^{\bullet}{ }_{2}^{-} \text {via } \\
\text { dismutation it into } \mathrm{O}_{2} \text { and } \\
\mathrm{H}_{2} \mathrm{O}_{2}\end{array}$ & $\begin{array}{r}\mathrm{O}_{2}^{--}+\mathrm{O}_{2}^{--}+2 \mathrm{H}^{+} \\
\Downarrow \\
2 \mathrm{H}_{2} \mathrm{O}_{2}+\mathrm{O}_{2}\end{array}$ & $\begin{array}{l}\text { Torun et al. } \\
\text { (2019) } \\
\text { Gulzar et al. } \\
\quad(2021)\end{array}$ \\
\hline $\begin{array}{r}\text { Catalase } \\
(\text { CAT })\end{array}$ & $\begin{array}{l}\text { Tetrameric heme-containing enzyme and } \\
\text { has high affinity for } \mathrm{H}_{2} \mathrm{O}_{2} \text { and has a } \\
\text { completely high turnover rate } \\
\left(6 \times 10^{6} \text { molecules of } \mathrm{H}_{2} \mathrm{O}_{2} \text { to } \mathrm{H}_{2} \mathrm{O}\right. \\
\text { and } \mathrm{O}_{2} \text { in one minute) }\end{array}$ & $\begin{array}{l}\text { 1. CAT1 which is } \\
\text { expressed in pollen } \\
\text { and seeds (residing in } \\
\text { peroxisomes and } \\
\text { cytosol) } \\
\text { 2. CAT2 in } \\
\text { photosynthetic tissues } \\
\text { (present in } \\
\text { peroxisomes and } \\
\text { cytosol) } \\
\text { 3. CAT3 which is } \\
\text { present in leaves and } \\
\text { vascular tissues } \\
\text { (localized within the } \\
\text { mitochondria) } \\
\text { 4. CAT activity increases } \\
\text { in leaves of barley and } \\
\text { provides resistance } \\
\text { against Bipolaris } \\
\text { sorokiniana } \\
\text { 5. Induction of CAT } \\
\text { activity provide } \\
\text { resistance against } \\
\text { Sclerotium rolfsii in } \\
\text { chickpea }\end{array}$ & $\begin{array}{l}\text { Dismutation of } \mathrm{H}_{2} \mathrm{O}_{2} \text { into } \\
\mathrm{H}_{2} \mathrm{O} \text { and } \mathrm{O}_{2}\end{array}$ & $\begin{array}{r}\mathrm{H}_{2} \mathrm{O}_{2} \\
\Downarrow \\
\mathrm{H}_{2} \mathrm{O}+(1 / 2) \mathrm{O}_{2}\end{array}$ & $\begin{array}{l}\text { Das and } \\
\text { Roychoudhury } \\
(2014 \mathrm{a}, \mathrm{b}) \\
\text { Sandalio et al. } \\
\quad(2021) \\
\text { Bhaduri and } \\
\text { Fulekar (2012) } \\
\text { Kaur et al. (2021) } \\
\text { Sahni and prasad } \\
\text { (2020) }\end{array}$ \\
\hline $\begin{array}{l}\text { Ascorbate } \\
\text { peroxidase } \\
(\mathrm{APX})\end{array}$ & Class I superfamily of heme peroxidases & $\begin{array}{l}\text { Exists in diverse } \\
\text { isoforms viz. cytosolic, } \\
\text { stromal, thylakoidal, } \\
\text { mitochondrial and } \\
\text { peroxisomal } \\
\text { Up-regulated activity of } \\
\text { peroxidase in rice } \\
\text { provides resistance } \\
\text { against Xanthomonas } \\
\text { oryzae } \\
\text { Upregulated activity of } \\
\text { peroxidase shows } \\
\text { resistance against } \\
\text { powdery mildew } \\
\text { disease in cucumber }\end{array}$ & $\begin{array}{l}\text { It utilizes ascorbate as } \mathrm{H}_{-} \\
\text {donor to breakdown } \mathrm{H}_{2} \mathrm{O}_{2} \\
\text { and releases water and } \\
\text { monodehydroascorbate } \\
\text { (MDHA) (Fig. 1) }\end{array}$ & $\begin{array}{r}\mathrm{H}_{2} \mathrm{O}_{2}+\mathrm{AA} \\
\Downarrow \\
2 \mathrm{H}_{2} \mathrm{O}+\mathrm{DHA}\end{array}$ & $\begin{array}{l}\text { Chiang et al., } \\
\text { (2015) } \\
\text { Caverzan et al. } \\
\text { (2016) } \\
\text { Kalaivani et al. } \\
\text { (2021) } \\
\text { Jogaiah et al. } \\
\text { (2020) }\end{array}$ \\
\hline $\begin{array}{l}\text { Glutathione } \\
\text { reductase } \\
(\mathrm{GR})\end{array}$ & $\begin{array}{l}\text { GR is a flavoprotein and an } \\
\text { oxidoreductase located in both } \\
\text { eukaryotes and prokaryotes }\end{array}$ & $\begin{array}{l}\text { Mainly, it is present in } \\
\text { chloroplasts with little } \\
\text { amounts present inside } \\
\text { the mitochondria and } \\
\text { cytosol } \\
\text { Increased activity of GR } \\
\text { provide resistance } \\
\text { against Alternaria } \\
\text { solani in tomato }\end{array}$ & $\begin{array}{l}\text { It catalyses reduction of } \\
\text { GSSG in NADPH } \\
\text { dependent manner and thus } \\
\text { is critical in maintaining } \\
\text { GSH pool }\end{array}$ & $\begin{array}{r}\text { GSSG }+ \text { NADPH } \\
\Downarrow \\
2 \mathrm{GSH}+\mathrm{NADP}\end{array}$ & $\begin{array}{l}\text { Bela et al., } \\
\text { (2018) } \\
\text { Dey et al. (2016) } \\
\text { Gulzar et al. } \\
\quad(2021)\end{array}$ \\
\hline
\end{tabular}


Fig. 1 Antioxidant defense system in plants to detoxify the reactive oxygen radicals generated during the stress condition. The induced defense is facilitated via defensive enzymes such as Peroxidases, Catalase, Superoxide Dismutase (SOD) and Ascorbate peroxidase (APX).SOD catalyzes the dismutation of $\mathrm{O}_{2}^{-}$ to $\mathrm{H}_{2} \mathrm{O}_{2}$, catalase (CAT) dismutases $\mathrm{H}_{2} \mathrm{O}_{2}$ to oxygen and water, and ascorbate peroxidase (APX) reduces $\mathrm{H}_{2} \mathrm{O}_{2}$ to water by utilizing ascorbate (ASC) as the specific electron donor. This antioxidant defense system is considered the main enzymatic system for protecting cells against oxidative damage

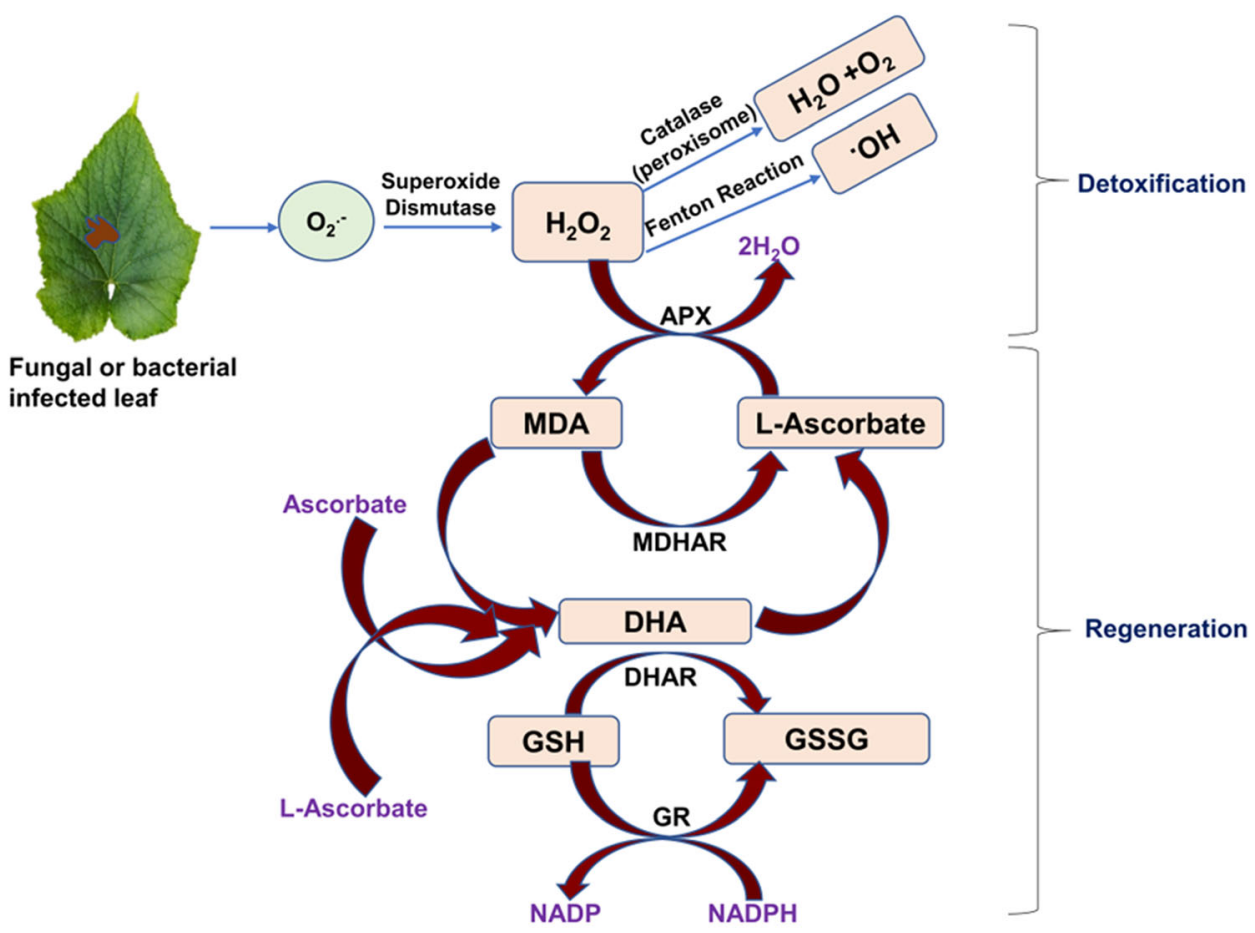

Metabolic alteration and synthesis of antimicrobial compounds

Many plant species produce a wide variety of toxic secondary metabolites for pathogens. The functions of secondary metabolites in plant defense include deterrence, toxicity and as a precursor to the physical defense system. The metabolic alteration in hosts consists of the synthesis of many antimicrobial proteins, enzymes and metabolites. All these host responses provide enough strength and rigidity to decrease the wounds caused by pathogens. Some important plant metabolites, enzymes and proteins are discussed here under the following section.

\section{Production of melatonin and its ecological roles against pathogens}

Melatonin is derived from serotonin that acts as an effective biocide against pathogens e.g., bacterial and fungal. The low dose of melatonin confers antimicrobial resistance against gram-positive and negative pathogenic bacteria (Tekbas et al. 2008). Melatonin confers antimicrobial activity by upregulating the pathogen-related, SA and ethylene signaling-associated gene and reducing the plant's susceptibility. Melatonin has also been found to be effective in decreasing the rate of infection after entry of the pathogens in plants (Arnao and Hernandez-Ruiz 2018), for example, the melatonin application also reduced the number of Pseudomonas syringae (the virulent bacterial pathogen) in infected leaves of Arabidopsis thaliana and 


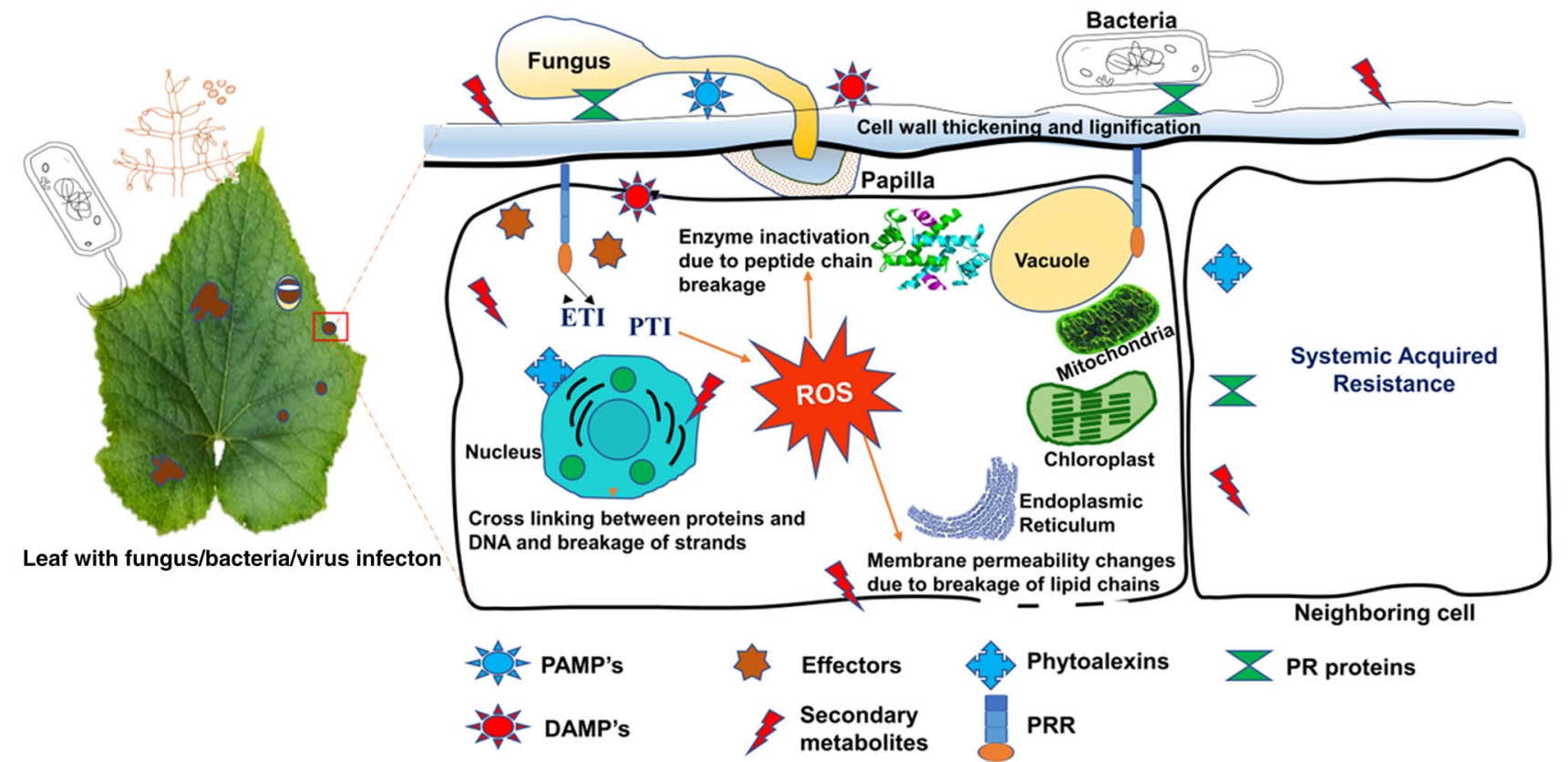

Fig. 2 Schematic representation of biochemical defense response by plant cell in response to plant pathogen (fungus, bacteria, etc.). Fungal germ tube growth is restricted by thickening of cell walls and formation of papilla. Biochemical defense response is triggered by PAMP-triggered immunity (PTI) and effector-triggered immunity (ETI) by the production of reactive oxygen species (ROS),

also revealed the involvement of melatonin, especially serotonin (Fujiwara et al. 2010) and N-acetyl serotonin (Lee et al. 2014) in activating defense signal molecules (elicitor) that triggers the expression of numerous defenserelated genes against $P$. syringae in Arabidopsis and tobacco (Lee et al. 2015). Furthermore, these findings were validated using diverse Arabidopsis mutants and hence revealing the involvement of melatonin action in the upstream of defense genes signaling pathway to biosynthesize various phytohormones i.e., salicylic acid, jasmonic acid and ethylene (Zhu et al. 2015) that together bring out disease resistance in a well-coordinated manner. Hence, the initial phase of plant-pathogen interaction results in enhanced ROS production (oxidative burst), which the plant takes care of by enhanced endogenous melatonin production (Lee et al. 2014). There are some interesting examples available, where fungi and bacteria live in plants in a mutualistic endophytic relationship and possess a higher level of melatonin than those plants where such mutualism does not occur (Jiao et al. 2016). Hence, this indicates an interesting area to examine the functions of melatonin levels in mutualistic relationships between plants and fungi to tackle the attack/infection against harmful microbes. phytoalexins, pathogenesis related (PR) protein and secondary metabolites like phenylalanine ammonia lyase, polyphenol oxidase, flavonoids etc. PAMPs and DAMPs initiate the PRR mediated immune response. Various secondary metabolites also act as signal molecules and intermediates for systemic acquired resistance (SAR) against pathogens in plants

\section{Elicitation of phytoalexins}

Phytoalexins are de novo synthesized antimicrobial compounds by plants, as part of the action to defend against invading pathogens. Phytoalexins provide disease-resistance against pathogens but the mode of action varies depending on the types of host-pathogen interaction. The majority of phytoalexins are toxic and repress the growth of pathogenic fungi, nematodes and bacteria. Accumulation of phytoalexin is controlled by the relevant biosynthetic enzymes that are induced by biotic and abiotic stressgenerated elicitors. The enhanced expression of biosynthetic enzyme coding genes increases the levels of phytoalexins. The response of the elicitors to induce the phytoalexin synthesis quickly (within minutes) stimulates de novo transcription of the corresponding genes. For example, Glyceollin (pathogen elicited phytoalexins) regulates resistance against Phytophthora sojae in soybean (Jahan et al. 2020. Like the localized cellular compartmentalization of phytoalexins during pathogen interaction, induction of the phytoalexin biosynthetic enzyme genes is also localized to the cells neighbouring the infection site. For example, Cocoa resistance to V. alboatrum has been linked with the localized phytoalexins production in the vicinity of the vessel (Cooper et al. 1996; Laouane et al. 2011). This helps to produce phytoalexins at 
Table 2 List of the different Phytoalexins identified in plants against various pathogens

\begin{tabular}{|c|c|c|c|c|}
\hline Plants & Pathogens or elicitors & $\begin{array}{l}\text { Biosynthesis pathways, signaling } \\
\text { components and other defense responses }\end{array}$ & Phytoalexins & References \\
\hline Alfa-alfa & $\begin{array}{l}\text { Fusarium oxysporum f. sp. } \\
\text { medicaginis }\end{array}$ & Flavonoid biosynthesis & $\begin{array}{l}\text { Medicarpin and 7,4'- } \\
\text { dihydroxyflavone }\end{array}$ & $\begin{array}{l}\text { Gill et al. } \\
\text { (2018) }\end{array}$ \\
\hline Pea & $\begin{array}{l}\text { Nectriahaemato cocca } \\
\text { and Mycosphaerella pinodes }\end{array}$ & Pisatin biosynthesis, Pisatin tolerance & Pisatin & $\begin{array}{l}\text { Coleman et al. } \\
(2011 \mathrm{a}, \mathrm{b})\end{array}$ \\
\hline \multirow[t]{2}{*}{ Soybean } & Fusarium solani & Phenylpropanoid pathway & Glyceollins & $\begin{array}{l}\text { Abdul, M and } \\
\text { Al-Muwayhi } \\
\text { (2020) }\end{array}$ \\
\hline & Colletotricum truncatum & Fatty acid synthesis pathway & Octanoic Acid & $\begin{array}{l}\text { Nose et al. } \\
(2022)\end{array}$ \\
\hline \multirow[t]{2}{*}{ Tobacco } & $\begin{array}{l}\text { Botrytis } \\
\text { cinerea and Phytophthora } \\
\text { nicotianae }\end{array}$ & Superoxide release, HR cell death & Scopoletin and capsidiol & $\begin{array}{l}\text { El Oirdi et al. } \\
\text { (2009) }\end{array}$ \\
\hline & A. tenuissi & Adverse effects on mycelial growth & Biphenyl & $\begin{array}{l}\text { Song et al. } \\
\quad(2021)\end{array}$ \\
\hline Grape & Agrobacterium rhizogenes & Tyrosine phosphorylation, cell death & Resveratrol & $\begin{array}{l}\text { Kiselev et al. } \\
\text { (2007) }\end{array}$ \\
\hline \multirow[t]{2}{*}{ Maize } & $\begin{array}{l}\text { Rhizopus } \\
\text { microsporus, Colletotrichum } \\
\text { graminicola, Fusarium } \\
\text { graminearum, } \\
\text { Cochliobolus heterostrophus } \\
\text { and Aspergillusflavus }\end{array}$ & $\begin{array}{l}\text { Kauralexin synthesis and jasmonic acid- } \\
\text { ethylene synergy }\end{array}$ & Kauralexins and zealexins & $\begin{array}{l}\text { Schmelz et al. } \\
\text { (2011) }\end{array}$ \\
\hline & $\begin{array}{l}\text { Fusarium graminearum and } \\
\text { Fusarium verticillioides }\end{array}$ & Flavonoid Biosynthesis & Xilonenin & $\begin{array}{l}\text { Forster et al. } \\
\text { (2022) }\end{array}$ \\
\hline Oat & Puccinia coronata & Avenanthramide biosynthesis & Avenanthramides & $\begin{array}{l}\text { Yang et al. } \\
(2004)\end{array}$ \\
\hline \multirow[t]{3}{*}{ Rice } & Magnaporthe oryzae & $\begin{array}{l}\text { Phytocassanes, momilactones and oryzalexin } \\
\text { synthesis, and HR-associated phytoalexin } \\
\text { biosynthesis }\end{array}$ & $\begin{array}{l}\text { Momilactone A and } \\
\text { momilactone B, } \\
\text { phytocassane A, } \\
\text { phytocassane E and } \\
\text { sakuranein }\end{array}$ & $\begin{array}{l}\text { Hasegawa } \\
\text { et al. (2010); } \\
\text { Ahuja et al. } \\
\text { (2012) }\end{array}$ \\
\hline & & Diterpenoids & Ent-10-oxodepressin & $\begin{array}{l}\text { Liang et al. } \\
(2021 \mathrm{a}, \mathrm{b})\end{array}$ \\
\hline & & Flavonoids biosynthesis & Tangeretin & $\begin{array}{l}\text { Liang et al. } \\
(2021 \mathrm{a}, \mathrm{b})\end{array}$ \\
\hline \multirow[t]{2}{*}{ Sorghum } & $\begin{array}{l}\text { Colletotrichum } \\
\text { sublineolum and Cochliobolus } \\
\text { heterostrophus }\end{array}$ & $\begin{array}{l}\text { Flavone biosynthesis from flavanones, } \\
\mathrm{H}_{2} \mathrm{O}_{2} \text { accumulation, papilla formation, } \\
\text { callose deposition, HRGP cross-linking, } \\
\text { cell death }\end{array}$ & $\begin{array}{l}\text { Luteolin, apigenin and } \\
\text { 3-deoxyanthocyanidins }\end{array}$ & $\begin{array}{l}\text { Liu et al. } \\
\text { (2010) }\end{array}$ \\
\hline & Fusarium & Anthocyanins synthesis pathway & 3-deoxyanthocynidin & $\begin{array}{l}\text { Nida et al. } \\
\text { (2021) }\end{array}$ \\
\hline Sugarcane & Colletotrichum falcatum & Phenyl propanoid biosynthesis pathway & 3-deoxy anthocyanidin & $\begin{array}{l}\text { Nandakumar } \\
\text { et al. }(2021)\end{array}$ \\
\hline Barely & $\begin{array}{l}\text { B. sorokiniana and Fusarium } \\
\text { graminearum }\end{array}$ & Chalcone synthesis & Methoxylchalcones & $\begin{array}{l}\text { Ube et al. } \\
\text { (2021) }\end{array}$ \\
\hline Lettuce & $\begin{array}{l}\text { Rhizoctonia solani and Olpidium } \\
\text { virulentus }\end{array}$ & Shikimate pathway & Benzoic acid and lettucenin A & $\begin{array}{l}\text { Windisch et al. } \\
\text { (2021) }\end{array}$ \\
\hline
\end{tabular}

higher rates and hence quickly controlling the pathogen proliferation in plants. The general function of the phytoalexin involves puncturing the cell wall of pathogens, disrupting their metabolism and reproductive functions and hence arresting the growth and development of invaded pathogens. 


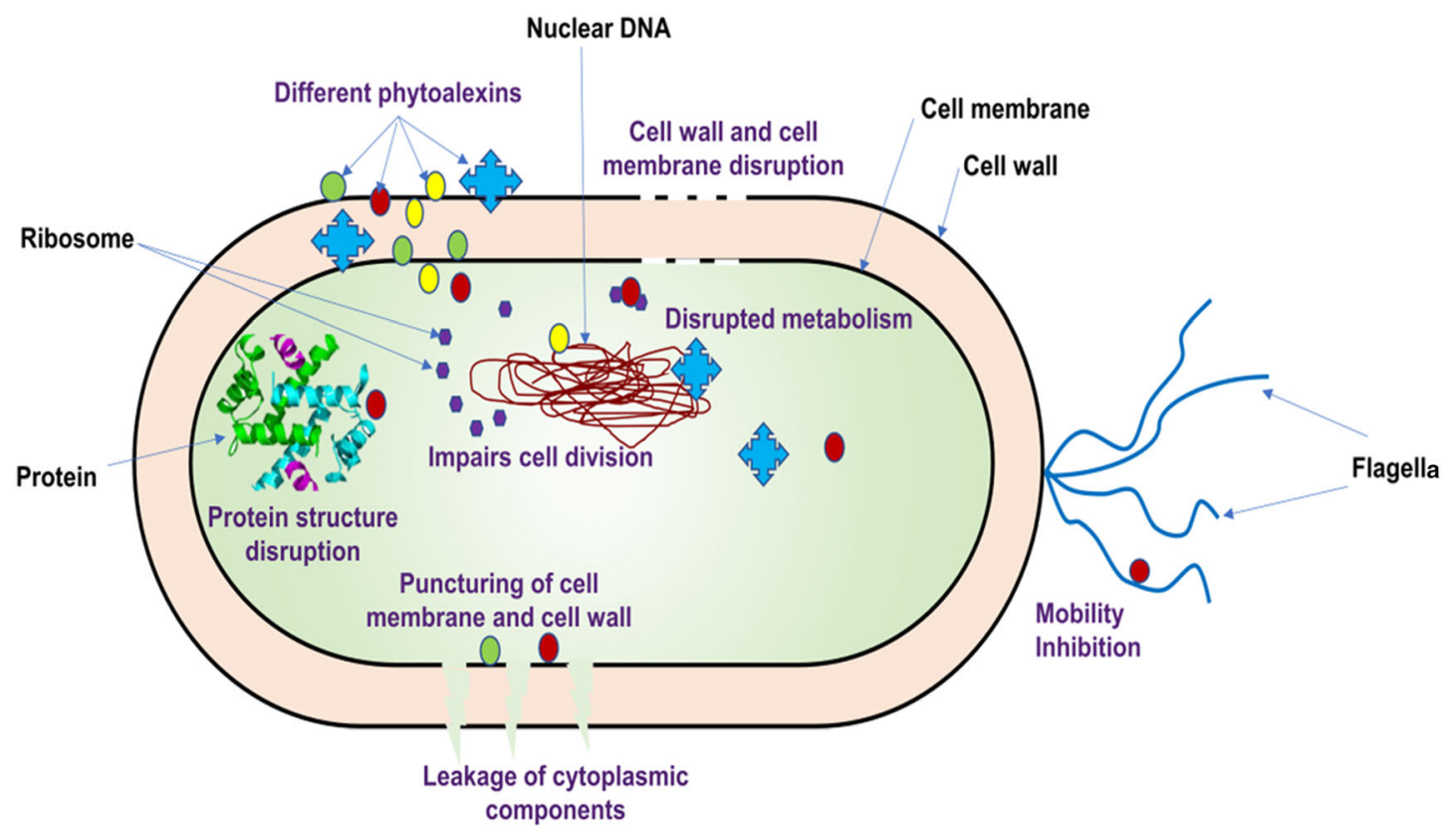

Fig. 3 Diagrammatic representation of mechanisms of phytoalexins against bacteria. Phytoalexins act in many ways, with each phytoalexin having a specific mode of action. It can either directly affect

To date, over 300 chemicals having phytoalexin-like characteristics have been identified belonging to over 30 plant families. The phytoalexins are family-specific. For example, sulfur-containing phytoalexins (like brassin) are most common among all Brassicaceae, while the Poaceae family possesses different phytoalexins like oryzalexins, zealexins, kauralexins, sakuranetin and phenyl amides (Arruda et al. 2016). Similarly, phenylpropanoid-related compounds, steroid glycoalkaloids sesquiterpenoids and coumarins are found in Solanaceae; and isoflavones, coumestans, phaseollin, stilbenes/resveratrol are restricted to the family Leguminosae. The list of phytoalexins identified against different diseases in various crops is presented in Table 2 and the mechanism of phytoalexins against bacteria is represented in Fig. 3. Chemically, phytoalexins are different, however, the majority of phytoalexins are the product of the Shikimic acid pathway through which the majority of the secondary metabolites are derived such as anthocyanins, flavonoids and lignin. The key enzymes such as PPO, PAL, 4-coumarate-CoA ligase $(4 \mathrm{CL})$, cinnamate 4-hydroxylase $(\mathrm{C} 4 \mathrm{H})$ and chalcone synthase (CHS) involved in this pathway serve a significant part in defense- mechanisms.

\section{Phenylalanine ammonia lyase (PAL) role in plant resistance}

PAL, consisting of tetramer with each subunit of $77-83 \mathrm{kDa}$, is an extensively studied enzyme (Jendresen the cell via membrane disruption and cell metabolites or indirectly by movement or cell multiplication

et al. 2015) as its the chief enzyme in the metabolism of phenylpropanoid and aids in synthesizing several secondary metabolites which include phenols (coumarins, flavonoids, lignins), phenolic derivatives and lignin (Bhattacharjee et al. 2017). The activity of PAL increases with the infection in several pathosystems (You et al. 2020). PAL activity in the leaves of resistant cultivars of barley genotypes increased against infection spot blotch pathogen B. sorokiniana (Kaur et al. 2021). Resistant reaction mainly occurs due to the defense of the cell walls by lignin intensification and the cell wall-bound phenolic compounds accumulation (Jun et al. 2018). In transgenic tobacco, reduction in lesion size and the number has also been witnessed in plants with PAL over-expression after getting infected with $P$. syringae. Similarly, bread wheat exhibited PAL gene AevPAL1 confers resistance to cereal cyst nematode by affecting the synthesis of salicylic acid and downstream secondary metabolites (Zhang et al. 2021). These studies indicate that PAL over-expression in plants provides disease resistance.

\section{Role of polyphenol oxidase (PPO) in plant resistance}

PPO has three domains which include: i) an N-terminal plastid transit peptide ii) a highly conserved type-3 copper center and iii) a C-terminal part. The PPO catalyzes the oxidation of monophenols and o-diphenols to o-quinones and is broadly scattered amongst bacteria, fungi, plants and animals (Boeckx et al. 2015). Direct effect of PPO on 
photosynthesis in walnut (Juglans regia) and also as an oxygen buffer or water-water cycle to facilitate reactive oxygen scavenging (Araji et al. 2014). For example, in different pearl millet cultivars, the level of PPO was positively correlated with the incidence of downy mildew resistance (Raj et al. 2006). In another investigation, potato plants resistant to bacterial wilt exhibited relatively enhanced expression of PPO after infection with Ralstonia solanacearum than the susceptible plants (El-Argawy and Adss 2016). In tomato plants, the over-expressed PPO exhibited increased resistance to $P$. syringae. Khodadadi et al. (2020)reported transgenic tobacco lines reduced the severity of disease symptoms with a reduced population of bacteria.

\section{Flavonoids}

Knowingly, higher plants are rich in flavonoids that occur within the leaves and floral organs. Based on their chemical structure, they are categorized under four groups, namely, flavonols, flavones, isoflavones and anthocyanins. Flavonoids perform important roles in providing protection from pathogens as well as in pigmentation to flowers and other plant parts (Fini et al. 2011). In plants, flavonoids are regarded as one of the secondary ROS scavenging systems experiencing destruction to the photosynthetic pigments because of extra excitation power. Agati et al. (2012) reported that they are important in scavenging ${ }^{1} \mathrm{O}_{2}$ and mitigating the destruction that happened to the outer envelope of the chloroplast membrane. For example, antibacterial flavonoids selectively target bacterial cells, inhibit virulence factors and reduce biofilm formation by interfering with quorum sensing (Gorniak et al. 2019). A study was carried out on the role of flavonoids on cotton wilt resistance. Metabolomics and transcriptomic analysis displayed flavonoids enrichment in leaves because of the upregulation of flavonoid biosynthesis genes. Also, in the red cotton cultivar, the fungal-pathogen invasion activity of Verticillium dahliae was suppressed because of the enhanced levels of flavonoids (Long et al. 2019). Identified Bayogenin 3-O-cellobioside (Norvienyeku et al. 2020), probenazole-inducible protein 1 (PBZ1), and phenylpropanoid accumulated (Ma et al. 2020) by metabolomics study of rice, are correlated with blast resistance. Metabolomics showed the accumulation of flavonoid compounds and plants coping with $C$. gloeosporioides by biosynthesis of flavonoid compounds providing potential targets for resistance breeding (Jiang et al. 2021).

\section{Lignin deposition}

Plants tend to deposit the lignin and callose in the cell wall to encounter the attack from pathogens. Enzymes such as
CAD, PAL and POX are involved in the biosynthesis of lignin. Enhanced activity of these enzymes during pathogen infection indicates their substantial role in plant defense (Scott-Craig et al. 1995). Hence, one of the common responses of plant defense is enhanced lignification (Vance et al. 1980). For instance, wheat varieties that were infected with spot blotch-pathogen exhibited a better lignification response (Eisa et al. 2013). The lipid peroxidation leads to MDA production in response to stress conditions, therefore, MDA content is a lipid peroxidation indicator (Malencic et al. 2004) and used as a marker for cellular damage caused due to stress. Phenolic compounds can also contribute to strengthening host cell components with the aid of lignin and suberin biosynthesis providing act as a physical barrier to pathogens. For example, in olive plantations, "Olive Quick Decline Syndrome" tolerant cultivar has been shown to decrease in disease progression through lignification of cell wall against $X$. fastidiosa (Sabella et al. 2018). Similarly, in potatoes, leaf xylem tissue lignifications (induced by the biocontrol fungus Trichoderma viride) have been found to decrease the severeness of late blight disease (Purwantisari et al. 2020). The various biochemical metabolites and cell wall components that have major contributions to disease resistance in different crops are presented in Table 3.

\section{Role of carotenoids as non-enzymatic antioxidants}

Carotenoids are yellow, red and orange color pigments. $\mathrm{C}_{40}$ isoprenoids possess a long-conjugated polyene chain that is accountable for their coloration and biological activities. The unique characteristic of carotenoids, i.e., a polyene backbone together with a chain of conjugated $\mathrm{C}=\mathrm{C}$ bonds is responsible for both their pigmentation properties and ability to interact with free radicals and singlet oxygen. This property makes carotenoids powerful antioxidants in the plant system (Paznocht et al. 2017). Carotenoids show their anti-oxidative potential by safeguarding the photosynthetic system in the following manners (i) it reacts with the products of lipid peroxidation to end the chain reactions, (ii) scavenges ${ }^{1} \mathrm{O}_{2}$ and heat dissipation, (iii) prevents ${ }^{1} \mathrm{O}_{2}$ formation by reacting with ${ }^{3} \mathrm{Chl}_{*}$ and excited chlorophyll $\left(\mathrm{Chl}_{*}\right)$ (Young and Lowe 2018). According to the studies of Mohamad and Bahman (2018), potato plants challenged with Rhizoctonia solani and treated with SA showed an increase in carotenoid content which further provided strong antioxidants to the potato plant system resulting in lower disease incidence.

\section{Polyamines and their response towards biotic stresses}

Polyamines alter in plant cells when they interact with fungal, bacterial and viral pathogens (Asthir et al. 2004) 
Table 3 List of studies of various biochemical metabolites and cell wall components for providing disease resistance in different crops

\begin{tabular}{|c|c|c|c|c|}
\hline $\begin{array}{l}\text { S. } \\
\text { No }\end{array}$ & Crop & Pathogen & Response & References \\
\hline 1 & Barley & $\begin{array}{l}\text { Puccinia striiformis } \mathrm{f} . \mathrm{sp} . \\
\text { Hordei (causing stripe rust in } \\
\text { barley) }\end{array}$ & $\begin{array}{l}\text { Leaves of the resistant cultivar (RD 2901) showed an increase in } \\
\text { activities of NADPH oxidase, catalase, peroxidase, and enzymes of } \\
\text { ascorbate-glutathione pathway at the seedling stage }\end{array}$ & $\begin{array}{l}\text { Singla et al. } \\
\text { (2019) }\end{array}$ \\
\hline 2 & Chickpea & $\begin{array}{l}\text { Helicoverpa armigera (Insect } \\
\text { pest) }\end{array}$ & $\begin{array}{l}\text { Resistant genotypes showed the integrative effect of up-regulated } \\
\text { defensive components in leaves, pod walls and seeds such as enhanced } \\
\text { activities of catalase, peroxidase, glutathione reductase. Polyphenol } \\
\text { oxidase and phenylalanine ammonia lyase, and accumulation of } \mathrm{H}_{2} \mathrm{O}_{2} \\
\text { and total phenols }\end{array}$ & $\begin{array}{l}\text { Kaur et al. } \\
\text { (2017) }\end{array}$ \\
\hline 3 & Castor & Fusarium oxysporum f. sp. ricini & $\begin{array}{l}\text { Thickening of the cell wall, Increased activities of defense enzymes viz, } \\
\text { superoxide dismutase (SOD), peroxidase (POX), catalase (CAT), } \\
\text { ascorbate peroxidase (APX), glutathione reductase (GR) and } \beta-1 \text {, } \\
\text { 3-glucanase (PR protein) in resistant cultivars as compared to } \\
\text { the susceptible cultivar }\end{array}$ & $\begin{array}{l}\text { Bharathi } \\
\text { et al, (2019) }\end{array}$ \\
\hline 4 & Barley & $\begin{array}{l}\text { Puccinia striiformis } \mathrm{f} . \mathrm{sp} . \\
\text { Hordei (causing stripe rust in } \\
\text { barley) }\end{array}$ & $\begin{array}{l}\text { RD2901 (resistant behavior) depicted increased levels of PR proteins, } \\
\text { phenylalanine ammonia lyase (PAL), tyrosine ammonia lyase (TAL) } \\
\text { and accumulated } \beta \text {-glucan and lignin in the plant cell wall during plant- } \\
\text { pathogen interaction }\end{array}$ & $\begin{array}{l}\text { Singla et al. } \\
\text { (2020) }\end{array}$ \\
\hline \multirow[t]{3}{*}{5} & \multirow[t]{3}{*}{ Rice } & \multirow[t]{3}{*}{$\begin{array}{l}\text { Magnaporthe } \\
\text { oryzae }\end{array}$} & $\begin{array}{l}\text { Activity of phenylalanine ammonia lyase (PAL) was induced in rice } \\
\text { plants in response to the fungal pathogen }\end{array}$ & $\begin{array}{l}\text { Giberti et al. } \\
\text { (2012) }\end{array}$ \\
\hline & & & Bayogenin 3-O-cellobioside accumulated & $\begin{array}{l}\text { Norvienyeku } \\
\text { et al. (2020) }\end{array}$ \\
\hline & & & $\begin{array}{l}\text { Probenazole-inducible protein } 1 \text { (PBZ1), and phenylpropanoid } \\
\text { accumulated and provide blast resistance }\end{array}$ & $\begin{array}{l}\text { Ma et al. } \\
(2020)\end{array}$ \\
\hline 6 & Wheat & Alternaria triticina & $\begin{array}{l}\text { Total phenol contents were significantly higher in resistant varieties } \\
\text { compared to the susceptible ones }\end{array}$ & $\begin{array}{l}\text { Mishra et al. } \\
\text { (2011) }\end{array}$ \\
\hline \multirow[t]{2}{*}{7} & \multirow[t]{2}{*}{ Tomato } & Ralstonia solanacearum & $\begin{array}{l}\text { Activities of phenylalanine ammonia lyase (PAL) and polyphenol } \\
\text { oxidase were significantly higher in resistant cultivars along with the } \\
\text { increase in total phenolic content as compared to the susceptible } \\
\text { cultivars }\end{array}$ & $\begin{array}{l}\text { Vanitha } \\
\text { et al., } \\
(2009)\end{array}$ \\
\hline & & Alternaria alternata & $\begin{array}{l}\text { Chitinase and } \beta-1,3 \text {-glucanase induction in tomato cause fruit defense } \\
\text { mechanism against } A \text {. alternata infection }\end{array}$ & $\begin{array}{l}\text { Cota et al. } \\
\text { (2007) }\end{array}$ \\
\hline \multirow[t]{2}{*}{8} & \multirow[t]{2}{*}{ Arabidopsis } & Powdery mildew & $\begin{array}{l}\text { Elevated early callose deposition results in complete penetration } \\
\text { resistance }\end{array}$ & $\begin{array}{l}\text { Ellinger et al. } \\
\text { (2013) }\end{array}$ \\
\hline & & Pseudomonas syringae & $\begin{array}{l}\text { Glycosylation and accumulation of N-hydroxy pipecolic acid provide } \\
\text { defense against Pseudomonas syringae }\end{array}$ & $\begin{array}{l}\text { Holmes et al. } \\
\text { (2021) }\end{array}$ \\
\hline 9 & $\begin{array}{l}\text { Eruca } \\
\text { sativa }\end{array}$ & $\begin{array}{l}\text { Alternaria } \\
\text { brassicicola }\end{array}$ & $\begin{array}{l}\text { Induction of } \beta-1,3 \text { - glucanase and chitinase activities (PR proteins) in the } \\
\text { resistant cultivars }\end{array}$ & $\begin{array}{l}\text { Gupta et al. } \\
\text { (2013) }\end{array}$ \\
\hline 10 & Stylo & Colletotrichum gloeosporioides & $\begin{array}{l}\text { Metabolomics showed the increased accumulation of flavonoid } \\
\text { compounds and cope with } C \text {. gloeosporioides }\end{array}$ & $\begin{array}{l}\text { Jiang et al. } \\
(2021)\end{array}$ \\
\hline
\end{tabular}

e.g., spermine (Spm), performs a vital function as a mediator in providing defense against the various pathogens thus providing resistance to plants (Takahashi et al. 2004). The accumulation of spermidine in barley leaves was observed after infection with Puccinia hordei and Bgh(powdery mildew pathogen). However, it is difficult to investigate the contribution of polyamines in both host plants as well as in pathogenic fungi against stress. But studies exist that indicate the possibilities of controlling fungal diseases in plants by specifically inhibiting the biosynthesis of polyamines (Hussain et al. 2011).
Polyamines role in host-pathogen interaction revealed that accumulation of hydrogen peroxide because of spermidine induced degradation of polyamines and nitric oxide served a vital function in the interaction between host plant and pathogens (Yamasaki and Cohen 2006; Di Martino et al. 2013). Hence, manipulation of the key genes or upstream of the polyamine-biosynthesis pathway can impart tolerance against pathogens in plants. 


\section{Role of phenolics in defense mechanism}

Phenols guard the plant against pathogen attack or ultraviolet radiation (Shahidi and Yeo 2016). Phenols can interfere with the oxidation process by reacting with free radicals, chelating-metal ions and by scavenging oxygen (Masisi et al. 2016). As antioxidants, phenolic compounds prevent oxidative damage to cellular organelles and organic molecules such as proteins, membrane lipids, DNA and RNA. Additionally, they function as reducing agents, hydrogen donors and singlet oxygen quenchers (Wang et al. 2018). When pathogens attack, phenolic compounds are produced which are considered as a part of the active defense response in plants (Holub et al. 2019). Cherif et al. (1992) reported that the early and rapid phenolic accumulation at the site of injection results in isolation and limits the progression of pathogens.

Accumulating phenolics possess low molecular weight i.e. benzoic acid and the phenylpropanoids in reaction to infection and leads to slower growth of B. sorokiniana in barley and activation of various phytoalexins (Bashyal et al. 2011). Barley possesses higher antioxidant activity than other cereals which are contributed by higher contents of phenolic acids like trans-cinnamic, salicylic, ferulic, chlorogenic, p-hydroxybenzoic, protocatechuic, coumaric and vanillic acids. The different resistant wheat varieties possessed significantly higher total phenol contents as compared to those susceptible to Alternaria triticina (Mishra et al. 2011). The activity of PAL expression and the accumulation of phenolic compounds at the infection site has been linked to the resistance mechanism (Nicholson and Hammerschmidt, 1992). In wheat, the level of total phenolic content has been correlated with host resistance to numerous diseases e.g., Karnal bunt (Gogoi et al., 2001) and Alternaria blight (Mishra et al. 2011). Metabolomics studies revealed the involvement of phenolic compounds in plant-pathogen interactions (Castro-Moretti et al. 2020; Lopez-Fernandez et al. 2020). Phytohormone SA is the most studied defense-responsive phenolic compound (Lefevere et al. 2020). A comparative metabolomic study showed that the accumulation of N-OH-Pip (N-hydroxypipecolic acid) after bacterial infection, imparts SAR (Chen et al. 2020).

\section{Activation of pathogenesis-related $(P R)$ proteins}

In plants, PR proteins are produced to retaliate against various diseases such as fungal, bacterial, viral and viroid diseases, as well as some chemicals. PR proteins were first recognized in tobacco plants infected by the tobacco mosaic virus (TMV) (Dani et al. 2005). Most PR proteins exist within the intercellular areas, while, primary PR proteins occur inside the vacuole (Arabi et al. 2019). Some
PR proteins are basic and sensitive to degradation by proteolytic enzymes (in the case of tomato and potato). Carbohydrates aid in the synthesis of several defense biomolecules like phenolics and phytoalexins. The metabolism of sucrose, a major translocator of carbon in plants, gets seriously affected during disease (Kosova et al. 2014). Hence, the quality and quantity maintenance of sugars (as well as PR proteins generation and accumulation) against invading pathogens is pivotal.

PR proteins accumulate locally inside the infected and surrounding uninfected tissues hence, restricting the spread of infection to infected parts only. Liu et al. (2010) classified PR-proteins into 17 families like $\beta$-1, 3-glucanases, chitinases, peroxidases, thaumatin-like proteins, ribosomeinactivating proteins, thionins, non-specific lipid switch proteins, oxalate oxidase and oxalate oxidase-like proteins. Chitinases, a PR-1 family protein cleaves the bond between $\mathrm{C} 1$ and $\mathrm{C} 4$ of chitin's consecutive $\mathrm{N}$-acetylglucosamine (NAG) monomers. Plant chitinases are usually endo-chitinases having the ability to degrade chitin (Suarez et al. 2001). Extracellular chitinases quickly block the spreading of the hyphae that invade internal areas. It also helps to release fungal elicitors that induce the synthesis of several other chitinases inside the host (Stangarlin and Pascholati 2000). Unlike other plant proteins, PR proteins are stabilized through disulfide linkages and hence are resistant to proteolysis and increased temperatures (Gorjanovic 2009). Here we have elaborated the functions of the chitinase and glucanase PR proteins family in disease-resistance.

\section{Role of chitinase and glucanase enzymes during pathogen infection}

In plants, $\beta-1,3$-glucanases belong to the PR-2 family of PR proteins (Ji et al. 2000). $\beta$-1, 3-glucanases can cleave the $\beta$-1,3-glycosidic bond in $\beta$-1,3-glucan, a major cell wall component of Oomycetes. In contrast to chitinases, $\beta$ 1, 3-glucanase (called callose in plants) is more important in plant life as indicated from their role in various other physiological functions, apart from plant defense (Anguelova et al. 2001). $\beta$-1, 3-glucanase plays direct as well as indirect actions to safeguard the plants from fungal pathogens via causing hydrolysis and lysis of fungal cell walls and oligosaccharide elicitors formation for the generation of various PR proteins or phytoalexins, respectively (Ebrahim et al. 2011). Chitinases and $\beta$-1, 3-glucanase are the most significant hydrolytic enzymes amongst PR proteins produced in several plant taxa after encountering various pathogen infections (Sels et al. 2008), for example, their increased concentration offers protection to the plants against fungal pathogens via degradation of the cell wall as it contains the vital substances i.e., chitin and $\beta-1,3$-glucan (Santen et al. 2005). After fungal infection, $\beta-1$, 
3-glucanases expressed in coordination with chitinases as cited from different crops like the bean, pea, tomato, maize, tobacco, soybean, wheat, barley and potato (Sels et al. 2008). Wheat infection with stripe rust fungus ( $P$. striiformis f. sp. tritici) has increased chitinase activity by upregulating TaBZR2, which confer broad-spectrum resistance (Bai et al. 2021).

\section{Transcription factors and regulatory elements}

Transcription factors (TFs) regulate gene expression through binding to specific sequences in the promoters of their target genes. TFs play roles at several levels of resistance by transcriptional reprogramming: (a) activate receptor proteins directly by TF (b) basal resistance components expression (e.g., response suppression proteins, receptors, kinases), (c) activation of downstream of receptor initiation (i.e., MAPK cascade leading to TF activation via phosphorylation) (Franco-Zorrilla et al. 2014; Lu et al. 2011). Upon infection to pathogens, plants respond via altered transcriptional reprogramming of the TF families like AP2/ERF, bHLH, bZIP, MYB, NAC and WRKY (Samota et al. 2017; Tsuda and Somssich 2015). For eg. in rice, Ideal Plant Architecture 1 (IPA1) TF imparts the resistance against rice blast infection by regulating (activating) the expression of WRKY45, a pathogen defense gene (Wang et al. 2018). Similarly, OsWRKY53 imparts resistance against rice blast in rice (Chujo et al. 2007). This indicates WRKY53 plays a prominent role in regulating the release of ROS, throughout the hypersensitive response. TF TaRIM1 ( $R$. cerealis-induced MYB confers resistance to sharp eyespot disease in wheat via modulating defense genes (Shan et al. 2016). Similarly, ORK10/LRK10 are defense regulator receptor kinases that impart resistance against fungal diseases in cereal crops (Marcel et al. 2010).

The regulatory element, GCC-box elements represent the hallmark of the promoters of aphid- and pathogen-responsive genes (Dong et al. 2010). Conclusively, defense genes such as WRKY53 impart broad-spectrum resistance through the transfer of wide-stream responsive signals to the other defense-related genes in proximity (upstream and downstream). Hence, the signaling crosstalk of the TFs for disease resistance seems a promising domain of research in crops.

\section{How can plant metabolites be used in crop improvement?}

Metabolomics measures the metabolite abundance and environmentally induced changes in metabolites concentration, as a predictive biomarker for disease diagnosis.
Metabolic markers are a sub-category of biomarkers, which reflect the compounds involved in plant metabolism (Fernandez et al. 2016; Zaynab et al. 2019). During biotic stresses, plants accumulate numerous metabolites often tissue and species-specific, that can function as biomarkers for biotic stress resistance (Razzaq et al. 2019). Such metabolites that can be used to provide tolerance against biotic or abiotic stresses are regarded as defensive diagnostic or metabolite markers. In plants, single metabolic markers have been suggested to assess the stress intensity, e.g., proline, which accumulates drought stress-prone plant species (Hayat et al. 2012). Later, metabolic variables were found to be useful markers to detect stress damage or resistance and hence the diagnostic markers have been developed in the form of enzymes (Gibon et al. 2004), metabolites (Korn et al. 2010; Duan et al. 2021), transcripts (Tamaoki et al. 2013) and amino acids (Zhao et al. 2021).

\section{Metabolic markers for disease resistance in crops}

Fridman et al. (2000) first proposed metabolic markers in 2000 , as a tool to map the metabolite quantitative trait loci (mQTLs) and find the related candidate genes. In 2007 for the very first time, metabolic profiling was carried out to evaluate the biomass performance in Arabidopsis thaliana (with a coefficient of correlation of 0.58 ) that opened new avenues in plant breeding where metabolic markers can be explored to find the allelic combinations for better plant performance (Meyer et al. 2007). Hence, metabolomics became an emerging technique for studying plant immunity, especially in interpreting the functions of small-sized molecules associated with plant-microbe interactions (Feussner and Polle 2015). Phytoalexins and pathogenesisrelated proteins are potential metabolite markers against wilt pathogen, Fusarium oxysporum in chickpea roots (Kumar et al. 2016). Similarly, Desalegn et al. (2016) identified the function of pisatin and pisatin biosynthesisassociated proteins in conferring resistance against Didymellapinodes in Pisum sativum. Lately, Seybold et al. (2020) performed metabolomics in wheat to elucidate the resistance mechanism against $Z$. tritici causing disease-resistant metabolites, i.e., trehalose, asparagine, phenylalanine, myoinositol, and L-alanine have been reported to serve as unique metabolite markers against Fusarium graminearum causing head blight in wheat (CuperlovicCulf et al. 2018). Zhou et al. (2019) reported smiglaside and smilaside as potential biomarkers against the Fusarium graminearum (head blight) in maize. Khizar et al. (2020) identified metabolites like phenylpropanoids (stilbenes and furanocoumarin), flavonoids (phlorizin and kaempferol), alkaloids (indolizine and acetylcorynoline) and terpenoids (azelaic acid and oleanolic acid) for leaf spot resistance (Aspergillus tubingensis) in cotton. Lately, Zhao et al. 
Table 4 Different metabolic markers associated with plants to impart resistance against stress

\begin{tabular}{|c|c|c|c|c|}
\hline Plants & $\begin{array}{l}\text { Resistant } \\
\text { against }\end{array}$ & Statistical approach & Metabolite accumulated/Reduced & References \\
\hline \multirow[t]{4}{*}{ Wheat } & $\begin{array}{l}\text { Fusarium } \\
\text { graminearum }\end{array}$ & $\begin{array}{l}\text { Fold change/ } \\
\text { Correlation } \\
\text { Network }\end{array}$ & $\begin{array}{l}\text { Phenolic acid, Phenylpropanoids,Trehalose, } \\
\text { Asparagine, Phenylalanine, Myoinositol,3- } \\
\text { hydroxybutarate, and L-alanine, Spermine, } \\
\text { Putrescine, GABA, Inositols, Galactose, and } \\
\text { Lactic acid }\end{array}$ & $\begin{array}{l}\text { Cuperlovic- } \\
\text { Culf et al. } \\
(2016,2018) \\
\text { Gunnaiah } \\
\text { et al. (2012) }\end{array}$ \\
\hline & $\begin{array}{l}\text { Wheat streak } \\
\text { mosaic virus }\end{array}$ & $\begin{array}{l}\text { PCA, KEGG, } \\
\text { METLIN, } \\
\text { MetFrag and } \\
\text { MetaboAnalyst }\end{array}$ & $\begin{array}{l}\text { Reduction in some amino acids such as L-tyrosine, } \\
\text { tryptophan, isoleucine and phenylalanine }\end{array}$ & $\begin{array}{l}\text { Farahbakhsh } \\
\text { et al. (2019) }\end{array}$ \\
\hline & $\begin{array}{l}\text { Triticum } \\
\text { turgidum }\end{array}$ & $\begin{array}{l}\text { PCA, XCMS } \\
\text { and CAMERA }\end{array}$ & Benzoxazinoids & $\begin{array}{l}\text { Shavit et al. } \\
\text { (2018) }\end{array}$ \\
\hline & $\begin{array}{l}\text { Fusarium } \\
\text { graminearum }\end{array}$ & PLS-DA & Proline and Alanine & $\begin{array}{l}\text { Zhou et al. } \\
\text { (2021) }\end{array}$ \\
\hline \multirow[t]{4}{*}{ Rice } & $\begin{array}{l}\text { Rhizoctonia } \\
\text { solani }\end{array}$ & - & Jasmonic acid, mucic acid, and glyceric acid & $\begin{array}{l}\text { Suharti et al. } \\
\text { (2016) }\end{array}$ \\
\hline & $\begin{array}{l}\text { Xanthomonas } \\
\text { oryzaepv. } \\
\text { oryzae }\end{array}$ & $\begin{array}{l}\text { KEGG, } \\
\text { MassHunter, } \\
\text { GeneSpring-MS } \\
1.2 \text { and } \\
\text { METLIN }\end{array}$ & $\begin{array}{l}\text { Phenylalanine and glutamine, linoleic acid lipids, } \\
\text { carbohydrates, alkaloids, xanthophylls, and } \\
\text { acetophenone }\end{array}$ & $\begin{array}{l}\text { Sana et al. } \\
\text { (2010) }\end{array}$ \\
\hline & $\begin{array}{c}\text { Orseolia } \\
\text { oryzae }\end{array}$ & ANOVA & $\begin{array}{l}\text { Heneicosanoic acid, Threonic acid, Palmitoleic } \\
\text { acid, Palmitic acid, Nonadecanoic acid and } \\
\text { Linoleic acid }\end{array}$ & $\begin{array}{l}\text { Agarrwal } \\
\text { et al. (2014) }\end{array}$ \\
\hline & $\begin{array}{l}\text { Magnaporthe } \\
\text { oryzae }\end{array}$ & $\begin{array}{l}\text { PCA, partial least squares discriminant } \\
\text { analysis (PLS-DA), and orthogonal partial } \\
\text { least squares discriminant analysis (OPLS- } \\
\text { DA) }\end{array}$ & $\begin{array}{l}\text { Shikimate, galactinol, trehalose, D-mannose, } \\
\text { linolenic acid, dopamine, tyramine, and } \\
\text { L-glutamine }\end{array}$ & $\begin{array}{l}\text { Duan et al. } \\
\text { (2021) }\end{array}$ \\
\hline Maize & $\begin{array}{l}\text { Fusarium } \\
\text { graminearum }\end{array}$ & $\begin{array}{l}\text { ANOVA and } \\
\text { SAS software }\end{array}$ & Smiglaside and Smilaside & $\begin{array}{l}\text { Zhou et al, } \\
2019\end{array}$ \\
\hline Cotton & $\begin{array}{l}\text { Aspergillus } \\
\text { tubingensis }\end{array}$ & PCA, OPLS-DA, PLS-DA & $\begin{array}{l}\text { Phenylpropanoids (stilbenes and furanocoumarin), } \\
\text { flavonoids (phlorizin and kaempferol), alkaloids } \\
\text { (indolizine and acetylcorynoline) and terpenoids } \\
\text { (azelaic acid and oleanolic acid) }\end{array}$ & $\begin{array}{l}\text { Khizar et al. } \\
(2020)\end{array}$ \\
\hline
\end{tabular}

(2021) identified proline and alanine as important metabolic markers for head blight resistance in wheat. In a recent study by Duan et al. (2021), metabolites namely shikimate, galactinol, trehalose, D-mannose, linolenic acid, dopamine, tyramine, and L-glutamine were identified as metabolic markers imparting plant defense response against rice blast. The list of different plant metabolic markers identified to provide resistance against the diseases has been given in Table 4 .

\section{Defense metabolites targeted breeding approaches}

Metabolomics based genome-wide association studies (mGWAS) and metabolic QTLs (mQTLs) are powerful and potential tools in detecting genetic variations associated with different metabolites in plants. Metabolic profiling helps in refining the genotype-phenotype association through the investigation of different important metabolites that provide biotic stress resistance. The mQTL/mGWAS helps in the identification of SNP markers-metabolites association resulting in pointing out the candidate genes governing biotic stress tolerance (Fernandez et al. 2016; Wen et al. 2016). However, the profiling of metabolites using electrospray ionization tandem mass spectrometry in mapping or GWAS (the sample size is quite large) is very costly and hence, is expensive to apply for a large sample size (Gieger et al. 2008; Gibon et al. 2012). Therefore, to study the genotype-metabolite associations, the bulk-sequencing-based approach like QTL-Seq can be a relatively more effective approach. In the bulk-seq approach, the bulk 


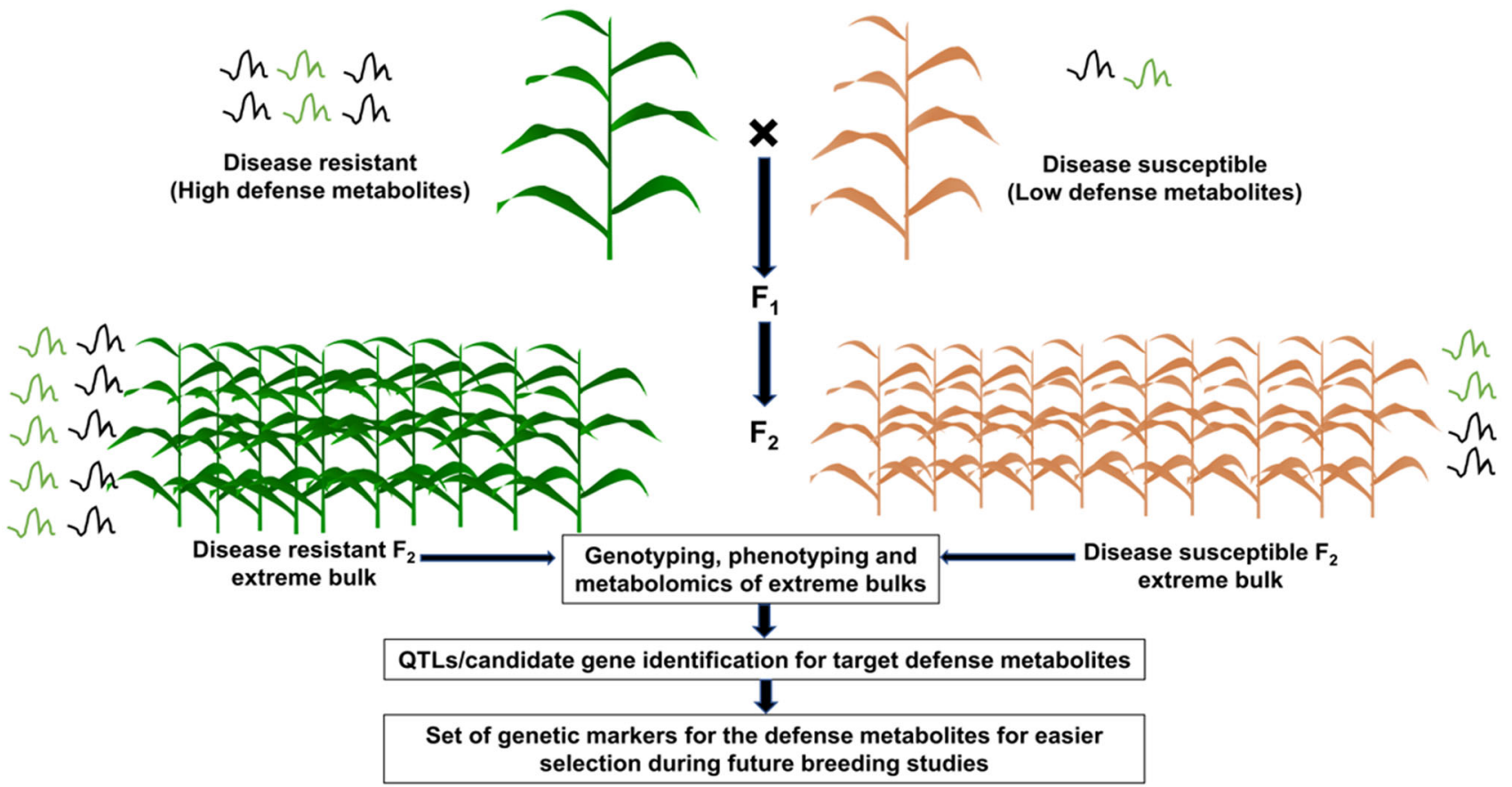

Fig. 4 Genomics assisted breeding approach for utilization of defense metabolites. The $\mathrm{F}_{2}$ population is generated by crossing the two contrasting genotypes and the extreme bulks identified on screening under artificial inoculation conditions (disease resistant and susceptible) are subjected to whole genome sequencing and metabolomics. One of the parents genome sequence is used as

of around 15-10 extreme phenotypes-resistant and susceptible (based on plant-pathogen reaction) can be selected and used for the metabolomics (Zou et al. 2016). Another approach is to use the subpanels of the germplasm but by ensuring the presence of diversity in sub-panels as the true indicator of the whole germplasm. Such approaches allow identifying a small set of reliable metabolite markers (hence reducing the cost) which can be employed by plant breeders for the effective selection of tolerant germplasm. Later, identification of key genetic markers related to such metabolomics markers can further help to reduce the cost of metabolomics-based breeding programs as sequencingbased markers are cheaper as compared to metabolite markers. Further, forward and reverse genetics can help validate the identified candidate genes for their role in the targeted metabolites synthesis.

The greater use of metabolites in crop improvement has been witnessed due to two important reasons. First, is the development of advanced next-generation sequencing platforms that provided ultra-high-density maps for the identification of mQTLs/candidate genes (Scossa et al. 2015). The second reason is the development and availability of easy-to-use, open-source and efficient statistical platforms for fast-forward analysis of metabolic and phenotypic data. For example, MetabR (http://metabr.r-forge.r- a reference to identify putative candidate genes and associated SNPs. The identified SNPs can serve as effective markers for the selection of resistant genotypes under future breeding programs such as marker assisted selection. Similarly, mGWAS concept can be applied to a representative diverse set of germplasm and establish marker-trait associations

project.org/), MetaboAnalystR(https://github.com/xialab/ MetaboAnalystR), and MetaboDi (http://github.com/ and reasmock/MetaboDi/a) are preferred $\mathrm{R}$ software packages for analysis of metabolomics due to open-source nature. The metabolomics can be integrated with the genomic sequencing technologies-based approaches (like transcriptomics and pan-genomics) to exploit the metabolic diversity in plants (Zhou and Liu 2022). The process of genomics assisted breeding approach for utilization of defense metabolites is represented in Fig. 4

\section{Concluding remarks and future perspectives}

The optimum and sustainable strategy for the management of plant diseases should be the targeted manipulation of naturally occurring defense mechanisms of host plants. In the recent past, remarkable efforts have been made for the identification of metabolites providing disease resistance in different crops. Different metabolites like enzymes, amino acids, lipids and organic acids have been identified as metabolic markers for disease resistance in different crops. Hence, the target of disease breeding programs should focus on the identification of metabolite markers involved in providing the resistance. The metabolic markers being 
more realistic performance indicator of the plants can be more effective than the molecular markers. However, the use of metabolite markers is a costly affair, especially when dealing with larger germplasm. Hence, such established metabolite markers can further be used to identify the closely linked genetic markers for diseases. The identified markers can be further validated and used for the identification of mQTLs and mGWAS. Such metabolites can also be used for genome-wide prediction to enhance the genetic gains in disease resistance breeding. Furthermore, the use of metabolites can be extended to epigenome-wide association studies and pan-genomics. The availability of the phenotypic data on the genotype's performance from the high throughput phenomics approach would also add an additional layer to correlate and establish relationships with the different metabolites. Hence, the collaborations between plant breeders, pathologists, statisticians and bioinformaticians would prove crucial to explore the omics (genomics, phenomics, metabolomics) to their fullest potential. Recently, the emerging approach of metabolome network studies (interactions between the different metabolites) opens the avenue for exploring the interaction of different metabolites in imparting disease. The utilization of resistance-related constitutive and induced metabolites in imparting plant disease resistance would be an interesting research domain to explore in near future. Therefore, it's the need of the hour to explore the natural metabolites in host plants to manage plant diseases effectively and sustainably.

Funding Open Access funding enabled and organized by CAUL and its Member Institutions.

\section{Declarations}

Conflicts of interest The authors whose names are listed above certify that they have NO affiliations with or involvement in any organization or entity with any financial interest (such as honoraria; educational grants; participation in speakers' bureaus; membership, employment, consultancies, stock ownership, or other equity interest; and expert testimony or patent-licensing arrangements), or non-financial interest (such as personal or professional relationships, affiliations, knowledge or beliefs) in the subject matter or materials discussed in this manuscript.

Open Access This article is licensed under a Creative Commons Attribution 4.0 International License, which permits use, sharing, adaptation, distribution and reproduction in any medium or format, as long as you give appropriate credit to the original author(s) and the source, provide a link to the Creative Commons licence, and indicate if changes were made. The images or other third party material in this article are included in the article's Creative Commons licence, unless indicated otherwise in a credit line to the material. If material is not included in the article's Creative Commons licence and your intended use is not permitted by statutory regulation or exceeds the permitted use, you will need to obtain permission directly from the copyright holder. To view a copy of this licence, visit http://creativecommons. org/licenses/by/4.0/.

\section{References}

Abdul M, Al-Muwayhi R (2020) Biotic stress as a defense mechanism in soybean (Glycine max L.) toward microbial pathogen: biochemical and physiological pathways study. Life Sci J 17(5):24-36. https://doi.org/10.7537/marslsj170520.02

Agati G, Azzarello E, Pollastri S, Tattini M (2012) Flavonoids as antioxidants in plants: location and functional significance. Plant Sci 196:67-76

Agarrwal R, Bentur JS, Nair S (2014) Gas chromatography mass spectrometry based metabolic profiling reveals biomarkers involved in rice-gall midge interactions. J Integr Plant Biol 56(9):837-848. https://doi.org/10.1111/jipb.12244

Ahuja I, Kissen R, Bones AM (2012) Phytoalexins in defense against pathogens. Trends Plant Sci 17:73-90

Akter S, Huang J, Waszczak C, Jacques S, Gevaert K, Breusegem FV (2015) Cysteines under ROS attack in plants: a proteomics view. J Exp Bot 66:2935-2944

Andersen EJ, Ali S, Byamukama E, Yen Y, Nepal MP (2018) Disease Resistance Mechanisms in Plants. Genes 9(7):339

Anguelova MV, Westhuizen VD, Pretorius ZA (2001) Beta-1,3glucanase and chitinase activities and the resistance response of wheat to leaf rust. J Phytopathol 149:381-384

Arabi E, Jawahar M, Al-daoude A, Al-shehadah E, Shoaib A, Imad M (2019) Differential expression of defense related genes in susceptible versus resistant barley genotypes challenged with Pyrenophora teres. Mycopath 15:61-66

Araji S, Grammer TA, Gertzen R (2014) Novel roles for the polyphenol oxidase enzyme in secondary metabolism and the regulation of cell death in walnut (Juglans regia). Plant Physiol 164:1191-1203

Arnao MB, Hernandez-Ruiz J (2018) Melatonin and its relationship to plant hormones. Ann Bot 121(2):195-207

Arruda RL et al (2016) An approach on phytoalexins: function, characterization and biosynthesis in plants of the family Poaceae. Cienc Rural 46(7):1206-1216

Asthir B, Spoor W, Duffus CM (2004) Involvement of polyamines, diamine oxidase and polyamine oxidase in resistance of barley to Blumeriagraminis f. sp Hordei. Euphytica 136:307-312

Asthir B, Koundal A, Bains NS, Mann SK (2010) Stimulation of antioxidative enzymes and polyamines during stripe rust disease of wheat. Biol Plant 54:329-333

Bai X, Zhan G, Tian S, Peng H, Cui X, Islam MA, Goher F, Ma Y, Kang Z, Xu Z-S, Guo J (2021) Transcription factor BZR2 activates chitinase Cht20.2 transcription to confer resistance to wheat stripe rust. Plant Physiol 187(4):2749-2762. https://doi. org/10.1093/plphys/kiab383

Bashyal BM, Chand R, Kushwaha C, Joshi AK, Kumar S (2011) Bipolaris sorokiniana of barley: infection behaviour in different members of Poaceae. Indian Phytopath 46:28-31

Bela K, Riyazuddin R, Horvath E, Hurton A, Galle A, Takacs Z, Zsigmond L, Szabados L, Tari I, Csiszar J (2018) Comprehensive analysis of anti-oxidant mechanism in Arabidopsis glutathione peroxidase -like mutants under salt and osmotic stress reveals organ specific significance of the At GPXL's activities. Environ Exp Bot 150:127-140

Bhaduri AM, Fulekar MH (2012) Antioxidant enzyme responses of plants to heavy metal stress. Rev Environ Sci Biotechnol 11:55-69 
Bharathi E, Lakshmi PS, Yadav P, Hameeda B (2019) Defense responses to fusarium oxysporum $\mathrm{f}$. sp. ricini infection in castor (Ricinus communis L.) cultivars. Indian Phytopath 72:647-656

Bhattacharjee P, Sarkar J, Chakraborty AP, Chakraborty U (2017) Biochemical responses in Sorghum bicolor and Triticum aestivum to spot blotch disease and induction of resistance by plant growth promoting rhizobacteria. J Mycol Plant Pathol 47:323-332

Bizuneh GK (2020) The chemical diversity and biological activities of phytoalexins. Tradit Med Adv. https://doi.org/10.1007/ s13596-020-00442-w

Boeckx T, Winters AL, Webb J, Smith AHK (2015) Polyphenol oxidase in leaves: is there any significance to the chloroplastic localization. J Exp Bot 66:3571-3579

Boller T, Felix G (2009) A renaissance of elicitors: perception of microbe-associated molecular patterns and danger signals by pattern-recognition receptors. Annu Rev Plant Biol 60:379-406

Castro-Moretti FR, Gentzel IN, Mackey D, Alonso AP (2020) Metabolomics as an emerging tool for the study of plantpathogen interactions. Metabolites 10(2):52

Caverzan A, Casassola A, Brammer SP (2016) Reactive oxygen species and antioxidant enzymes involved in plant tolerance to stress. Genet Mol Biol 39:1-6

Chen J, Ullah C, Reichelt M, Beran F, Yang Z-L, Gershenzon J et al (2020) The phytopathogenic fungus Sclerotinia sclerotiorum detoxifies plant glucosinolate hydrolysis products via an isothiocyanate hydrolase. Nat Commun 11(1):3090

Cherif M, Benhamou N, Menzies JG, Belanger RR (1992) Siliconinduced cellular defense reactions in cucumber plants attacked with Pythium ultimum. Physiol Mol Plant Pathol 41:411-425

Chiang CM, Chien HL, Chen LFO, Hsiung TC, Chiang MC, Chen SP, Lin KH (2015) Over expression of the genes coding ascorbate peroxidase from Brassica campestris enhances heat tolerance in transgenic Arabidopsis thaliana. Biol Plant 59:305-315

Chowdhury J, Henderson M, Schweizer P, Burton RA, Fincher GB, Little A (2014) Differential accumulation of callose, arabinoxylan and cellulose in non penetrated versus penetrated papillae on leaves of barley infected with Blumeria graminis f.sp. hordei. New Phytol 204:650-660

Chujo T, Takai R, Akimoto-Tomiyama C, Ando S, Minami E, Nagamura Y, Kaku H, Shibuya N, Yasuda M, Nakashita H, Umemura K, Okada A, Okada K, Nojiri H, Yamane H (2007) Involvement of the elicitor-induced gene OsWRKY53 in the expression of defenserelated genes in rice. Biochim Biophys Acta 1769:497-505

Coleman JJ, White GJ, Rodriguez-Carres M, Van Etten HD (2011a) An ABC transporter and a cytochrome P450 of Nectria haematococca MPVI are virulence factors on pea and are the major tolerance mechanisms to the phytoalexin pisatin. Mol Plant Microbe Interact 24(3):368-376. https://doi.org/10.1094/ MPMI-09-10-0198

Coleman JJ, White GJ, Rodriguez-Carres M, Etten HDV (2011b) An $\mathrm{ABC}$ Transporter and a cytochrome $\mathrm{P} 450$ of nectriahaematococca MPVI are virulence factors on pea and are the major tolerance mechanisms to the Phytoalexin Pisatin. Mol Plant Microbe Interact 24(3):368-376

Cooper RW, Resende MLV, Flood J, Rowan MG, Beale MH, Potter U (1996) Detection and cellular localization of elemental sulphur in disease-resistant genotypes of Theobroma Cacao. Nat 379(6561):159-162

Cota IE, Troncoso-Rojas R, Sotelo-Mundo R, Sánchez-Estrada A, Tiznado-Hernández ME (2007) Chitinase and $\beta$-13-glucanase enzymatic activities in response to infection by Alternaria alternata evaluated in two stages of development in different tomato fruit varieties. Scientia Horticulturae 112(1):42-50. https://doi.org/10.1016/j.scienta.2006.12.005
Cuperlovic-Culf M, Wang L, Forseille L, Boyle K, Merkley N, Burton I, Fobert P (2016) Metabolic biomarker panels of response to fusarium head blight infection in different wheat varieties. PLoS One. 11:e0153642

Cuperlovic-Culf M, Vaughan M, Vermillion K, Surendra A, Teresi J, McCormick S (2018) Effects of atmospheric CO2 level on the metabolic response of resistant and susceptible wheat to fusarium graminearum Infection. Mol Plant Microbe Interact. https://doi.org/10.1094/MPMI-06-18-0161-R

Dani V, Simon WJ, Duranti M, Croy RD (2005) Changes in the tobacco leaf apoplast proteome in response to salt stress. Proteomics 5:737-745

Das K, Roychoudhury A (2014) Reactive oxygen species (ROS) and response of antioxidants as ROS-scavengers during environmental stress in plants. Front Environ Sci. https://doi.org/10. 3389/fenvs.2014.00053

Das K, Roychoudhury A (2014b) Reactive oxygen species (ROS) and response of antioxidants as ROS-scavengers during environmental stress in plants. Front Environ Sci 2(53):1-13

Debona D, Rodrigues FA, Rios JA, Nascimento KJT (2012) Biochemical changes in the leaves of wheat plants infected by Pyriculariaoryzae. Phytopathology 102:1121-1129

Deepak S, Shailasree S, Kini RK, Muck A, Mithofer A, Shetty SH (2010) Hydroxyproline-rich glycoproteins and plant defense. J Phytopathol 158(9):585-593

Desalegn G, Turetschek R, Kaul HP, Wienkoop S (2016) Microbial symbionts affect Pisum sativum proteome and metabolome under didymellapinodes infection. J Proteomics 30(143):173-187

Dey S, Sidor A, Rourke BO (2016) Compartment-specific control of reactive oxygen species scavenging by antioxidant pathway enzymes. J Biol Chem 291:11185-97

Di Martino ML, Campilongo R, Casalino M, Micheli G, Colonna B, Prosseda G (2013) Polyamines: emerging players in bacteriahost interactions. Int J Med Microbiol 303(8):484-491

Dong N, Liu X, Lu Y, Du L, Xu H, Liu H, Xin Z, Zhang Z (2010) Overexpression of TaPIEP1, a pathogen-induced ERF gene of wheat, confers host-enhanced resistance to fungal pathogen Bipolarissorokiniana. Funct Integr Gen 10:215-226

Duan G, Li C, Liu Y, Ma X, Luo Q, Yang J (2021) Magnaportheoryzae systemic defense trigger 1 (MoSDT1)-mediated metabolites regulate defense response in Rice. BMC Plant Biol 21(1): $1-12$

Ebrahim S, Usha K, Singh B (2011) Pathogeneis related (PR) proteins in plant defense mechanism. Sci Microb Pathol 2:1043-1054

Eisa M, Chand R, Joshi AK (2013) Biochemical and histochemical traits: a promising way to screen resistance against spot blotch (Bipolarissorokiniana) of wheat. Eur J Plant Pathol 137:805-820

El OirdiTrapani MA, Bouarab K (2009) The nature of tobacco resistance against Botrytis cinerea depends on the infection structures of the pathogen. Environ Microbiol 12:239-253

El-Argawy E, Adss I (2016) Quantitative Gene Expression of Peroxidase, Polyphenoloxidase and Catalase as Molecular Markers for Resistance against Ralstonia Solanacearum. Am J Mol Biol $6: 88-100$

Ellinger D, Naumann M, Falter C, Zwikowics C, Jamrow T, Manisseri C, Somerville S, Voigt C (2013) Elevated early callose deposition results in complete penetration resistance to powdery mildew in arabidopsis. Plant Physiol 161(3):1433-1444

Farahbakhsh F, Hamzehzarghani H, Massah A, Tortosa M, Yasayee M, Rodriguez VM (2019) Comparative metabolomics of temperature sensitive resistance to wheat streak mosaic virus (WSMV) in resistant and susceptible wheat cultivars. J Plant Physiol 237:30-42

Fernandez O, Urrutia M, Bernillon S, Giauffret C, Tardieu F, Le Gouis J, Langlade N, Charcosset A, Moing A, Gibon Y (2016) 
Fortune telling: metabolic markers of plant performance. Metabolomics 12(10):1-14

Feussner I, Polle A (2015) What the transcriptome does not tellProteomics and metabolomics are closer to the plants' pathophenotype. Curr Opin Plant Biol 26:26-31

Fini A, Brunetti C, Ferdinando D, Ferrini F, Tattini M (2011) Stress induced flavonoid biosynthesis and the antioxidant machinery of plants. Plant Signal Behav 6:709-11

Forster C, Handrick V, Ding Y, Nakamura Y et al (2022) Biosynthesis and antifungal activity of fungus-induced O-methylated flavonoids in maize. Plant Physiol 188(1):167-190

Franco-Zorrilla JM, López-Vidriero I, Carrasco JL, Godoy M, Vera P, Solano R (2014) DNA-binding specificities of plant transcription factors and their potential to define target genes. In: Proceedings of the national academy of sciences of the United States of America, vol. 111(6): pp. 2367-2372. Doi: https://doi.org/10. 1073/PNAS.1316278111/-/DCSUPPLEMENTAL

Fridman E, Pleban T, Zamir D (2000) A recombination hotspot delimits a wild-species quantitative trait locus for tomato sugar content to $484 \mathrm{bp}$ within an invertase gene. Proc Natl Acad Sci 97(9):4718-4723

Fujiwara T, Maisonneuve S, Isshiki M, Mizutani M, Chen L, Wong HL, Kawasaki T, Shimamoto K (2010) Sekiguchi lesion gene encodes a cytochrome P450 monooxygenase that catalyzes conversion of tryptamine to serotonin in rice. J Biol Chem 285(15):11308-11313

Giberti S, Bertea CM, Narayana R, Maffei ME, Forlani G (2012) Two phenylalanine ammonia lyase isoforms are involved in the elicitor-induced response of rice to the fungal pathogen Magnaportheoryzae. J Plant Physiol 169(3):249-254

Gibon Y, Blaesing OE, Hannemann J, Carillo P, Hohne M, Hendriks JH, Palacios N, Cross J, Selbig J, Stitt M (2004) A robot-based platform to measure multiple enzyme activities in arabidopsis using a set of cycling assays: comparison of changes of enzyme activities and transcript levels during diurnal cycles and in prolonged darkness. Plant Cell 16(12):3304-3325

Gibon Y, Rolin D, Deborde C, Bernillon S, Moing A (2012) New opportunities in metabolomics and biochemical phenotyping for plant systems biology. In: Roessner DU (Ed.) Metabolomics. Rijeka: INTECH pp. 213-240.

Gieger C, Geistlinger L, Altmaier E, Hrabe de Angelis M, Kronenberg F, Meitinger T, Mewes HW, Wichmann HE, Weinberger KM, Adamski J, Illig T, Suhre K (2008) Genetics meets metabolomics: a genome-wide association study of metabolite profiles in human serum. PLoS Genet 4(11):e1000282

Gill US, Uppalapati SR, Gallego-Giraldo L, Ishiga Y, Dixon RA, Mysore KS (2018) Metabolic flux towards the (iso)flavonoid pathway in lignin modified alfalfa lines induces resistance against Fusarium oxysporum f Sp Medicaginis. Plant Cell \& Environ 41(9):1997-2007. https://doi.org/10.1111/pce.13093

Gill MB, Zeng F, Shabala L, Zhang G, Yu M, Demidchik V, Shabala S, Zhou M (2019) Identification of QTL related to ROS formation under hypoxia and their association with waterlogging and salt tolerance in barley. Int J Mol Sci 20:1-15

Gogoi R, Singh DV, Srivastava KD (2001) Phenols as a biochemical basis of resistance in wheat against Karnal bunt. Plant Pathol 50:470-476

Gorjanovic S (2009) A review: Biological and technological functions of barley seed pathogenesis - related proteins (PRs). J Inst Brew $115: 334-360$

Gorniak I, Bartoszewski R, Kroliczewski J (2019) Comprehensive review of antimicrobial activities of plant flavonoids. Phytochem Rev 18:241-272

Gulzar N, Ali S, Shah MA, Kamili AN (2021) Silicon supplementation improves early blight resistance in Lycopersicon esculentum Mill by modulating the expression of defense-related genes and antioxidant enzymes. Biotech 11(5):232

Gunnaiah R, Kushalappa AC, Duggavathi R, Fox S, Somers DJ (2012) Integrated metabolo-proteomic approach to decipher the mechanisms by which wheat QTL (Fhb1) contributes to resistance against Fusarium graminearum. PLoS ONE. 7:e40695

Gupta P, Ravi I, Sharma V (2013) Induction of $\beta$-1,3-glucanase and chitinase activity in the defense response of Eruca sativa plants against the fungal pathogen alternaria brassicicola. J Plant Interact 8:155-161

Gururani MA, Venkatesh J, Upadhyaya CP, Nookaraju A, Pandey SK, Park SW (2012) Plant disease resistance genes: current status and future directions. Physiol Mol Plant Pathol 78:51-65. https://doi.org/10.1016/J.PMPP.2012.01.002

Hasegawa M, Seo IMS, Lmai T, Koga J, Okada K, Yamane H, Ohashi Y (2010) Phytoalexin accumulation in the interaction between rice and the blast fungus. Mol Plant Microbe Interact 23(8):1000-1011. https://doi.org/10.1094/MPMI-23-8-1000

Hayat R, Ahmed I, Sheirdil RA (2012) An overview of plant growth promoting rhizobacteria (PGPR) for sustainable agriculture. In: Ashraf M, Ozturk M, Ahmad MSA, Aksoy A (eds) Crop production for agricultural improvement. Springer, Berlin, pp 557-579

Holmes EC, Chen YC, Mudgett MB, Sattely ES (2021) Arabidopsis UGT76B1 glycosylates N-hydroxy-pipecolic acid and inactivates systemic acquired resistance in tomato. Plant Cell 33(3):750-765

Holub P, Nezval J, Stroch M, Spunda V, Urban O, Jansen MA, Klem $\mathrm{K}$ (2019) Induction of phenolic compounds by UV and PAR is modulated by leaf ontogeny and barley genotype. Plant Physiol Biochem 134:81-93

Hussain SS, Ali M, Ahmad M, Siddique KH (2011) Polyamines: natural and engineered abiotic and biotic stress tolerance in plants. Biotechnol Adv 29(3):300-311

Jahan MA, Harris B, Lowery M, Infante AM, Percifield RJ, Kovinich N (2020) Glyceollin transcription factor GmMYB29A2 regulates soybean resistance to Phytophthora sojae. Plant Physiol 183(2):530-546. https://doi.org/10.1104/pp.19.01293

Jendresen CB, Stahlhut SG, Li M, Gaspar P, Solvej S, Forster J, Maury J, Borodina I, Nielsen AT (2015) Highly active and specific tyrosine ammonia-lyases from diverse origins enabvle enhanced production of aromatic compounds in bacteria and Saccharomyces cerevisiae. Appl Environ Microbiol 81:4458-4476

Ji C, Norton RA, Wicklow DT, Dowd PF (2000) Isoform patterns of chitinase and $\beta$-1,3-glucanase in maturing corn kernels (Zea mays L.) associated with Aspergillus flavus milk stage induction. J Agric Food Chem 48:507-511

Jiang L, Wu P, Yang L, Liu C, Guo P, Wang H, Wang S, Xu F, Zhuang Q, Tong X et al (2021) Transcriptomics and metabolomics reveal the induction of flavonoid biosynthesis pathway in the interaction of Stylosanthes-Colletotrichum gloeosporioides. Genomics 113:2702-2716

Jiao J, Ma Y, Chen S, Liu C, Song Y, Qin Y, Yuan C, Liu Y (2016) Melatonin-producing endophytic bacteria from grapevine roots promote the abiotic stress-induced production of endogenous melatonin in their hosts. Front Plant Sci 7:1387

Jogaiah S, Satapute P, De Britto S, Konappa N, Udayashankar AC (2020) Exogenous priming of chitosan induces upregulation of phytohormones and resistance against cucumber powdery mildew disease is correlated with localized biosynthesis of defense enzymes. Int J Biol Macromol 162:1825-1838

Jones JDG, Dangl JL (2006) The plant immune system. Nat 444:323-329

Jun S-Y, Sattler SA, Cortez GS, Vermerris W, Sattler SE, Kang C (2018) Biochemical and structural analysis of substrate 
specificity of a Phenylalanine Ammonia-Lyase. Plant Physiol 176(2):1452-1468. https://doi.org/10.1104/pp.17.01608

Kalaivani K, Maruthi-Kalaiselvi M, Senthil-Nathan S (2021) Seed treatment and foliar application of methyl salicylate (MeSA) as a defense mechanism in rice plants against the pathogenic bacterium, Xanthomonas oryzae pv. Oryzae. Pestic Biochem Physiol 171:104718

Kaur A, Grewal SK, Singh R, Kaur J (2017) Defense system in chickpea genotypes differing in tolerance to Helicoverpa armigera infestation. Indian J Plant Physiol 22:324-331

Kaur S, Bhardwaj RD, Kaur J, Kaur S (2021) Induction of defenserelated enzymes and pathogenesis-related proteins imparts resistance to barley genotypes against spot blotch disease. J Plant Growth Regul. https://doi.org/10.1007/s00344-02110333-2

Keane P (2012) How pathogens attack plants. Microbiol Aust Microbiol Aust 33(1):26-28

Khizar M, Shi J, Saleem S, Liaquat F, Ashraf M, Latif S, Haroon U, Hassan SW, Rehman SU, Chaudhary HJ, Quraishi UM (2020) Resistance associated metabolite profiling of Aspergillus leaf spot in cotton through non-targeted metabolomics. PloS one 15(2): 0228675

Khodadadi F, Tohidfar M, Vahdati K, Dandekar AM, Leslie CA (2020) Functional analysis of walnut polyphenol oxidase gene (JrPPO1) in transgenic tobacco plants and PPO induction in response to walnut bacterial blight. Plant Pathol 69(4):756-764. https://doi.org/10.1111/ppa.13159

Kiselev KV, Dubrovina AS, Veselova MV, Bulgakov VP, Fedoreyev SA, Zhuravlev YN (2007) The rolB gene-induced overproduction of resveratrol in Vitisamurensis transformed cells. J Biotechnol 128(3):681-692

Korn M, Gartner T, Erban A, Kopka J, Selbig J, Hincha DK (2010) Predicting Arabidopsis freezing tolerance and heterosis in freezing tolerance from metabolite composition. Mol Plant 3:224-235

Kosova K, Vitamavas P, Prasil IT (2014) Proteomics of stress responses in wheat and barley-search for potential protein markers of stress tolerance. Front Plant Sci 5:1-14

Kumar A, Verma JP (2018) Does plant Microbe interaction confer stress tolerance in plants: a review. Microbiol Res 207:41-52

Kumar Y, Zhang L, Panigrahi P, Dholakia BB, Dewangan V, Chavan SG, Kunjir SM, Wu X, Li N, Rajmohanan PR, Kadoo NY, Giri AP, Tang H, Gupta VS (2016) Fusarium oxysporum mediates systems metabolic reprogramming of chickpea roots as revealed by a combination of proteomics and metabolomics. Plant Biotechnol J 14(7):1589-1603

Laouane H, Lazrek HB, Sedra MH (2011) Synthesis and toxicity evaluation of cinnamyl acetate: A new phytotoxin produced by a strain of Verticillium dahliae pathogenic on olive tree. Int $\mathrm{J}$ Agric Biol 13:444-446

Lee HY, Byeon Y, Back K (2014) Melatonin as a signal molecule triggering defense responses against pathogen attack in Arabidopsis and tobacco. J Pineal Res 57:262-268

Lee HY, Byeon Y, Tan DX, Reiter RJ, Back K (2015) Arabidopsis serotonin $\mathrm{N}$-acetyltransferase knockout mutant plants exhibit decreased melatonin and salicylic acid levels resulting in susceptibility to an avirulent pathogen. J Pineal Res 58(3):291-299

Lefevere H, Bauters L, Gheysen G (2020) Salicylic acid biosynthesis in plants. Front Plant Sci. https://doi.org/10.3389/fpls.2020. 00338

Li X, Bao H, Wang Z, Wang M, Fan B, Zhu C, Chen Z (2018) Biogenesis and function of multivesicular bodies in plant immunity. Front Plant Sci 9:979

Liang J, Shen Q, Wang L, Liu J, Fu J, Zhao L, Xu M, Peters RJ, Wang Q (2021a) Rice contains a biosynthetic gene cluster associated with production of the casbane-type diterpenoid phytoalexin ent10-oxodepressin. New Phytol 231(1):85-93

Liang M, Ye H, Shen Q, Jiang X, Cui G, Gu W, Zhang LH, Naqvi NI, Deng YZ (2021b) Tangeretin inhibits fungal ferroptosis to suppress rice blast. J Integr Plant Biol 63(12):2136-2149

Liu H, Du Y, Chu H, Shih CH, Wong YW, Wang M, Chu IK, Tao Y, Lo C (2010) Molecular dissection of the pathogen-inducible 3-deoxyanthocyanidin biosynthesis pathway in sorghum. Plant Cell Physiol 51(7):1173-1185

Long L, Liu J, Gao Y, Xu FC, Zhao JR, Li B, Gao W (2019) Flavonoid accumulation in spontaneous cotton mutant results in red coloration and enhanced disease resistance. Plant Physiol Biochem 143:40-49

Van Loon LC, Rep M, Pieterse CMJ (2006) Significance of inducible defense-related proteins in infected plants vol. 44: pp. 135-162. Https://Doi.Org/https://doi.org/10.1146/Annurev.Phyto.44. 070505.143425

Lopez-Fernandez O, Dominguez R, Pateiro M, Munekata PES, Rocchetti G, Lorenzo JM (2020) Determination of polyphenols using liquid chromatographytandem mass spectrometry technique (LC-MS/MS): a review. Antioxid (Basel, Switz) 9(6):479

Lu J, Ju H, Zhou G, Zhu C, Erb M, Wang X, Wang P, Lou Y (2011) An EAR-motif-containing ERF transcription factor affects herbivore-induced signaling, defense and resistance in rice. Plant J 68(4):583-596. https://doi.org/10.1111/J.1365-313X. 2011.04709.X

Ma Z, Wang L, Zhao M et al (2020) ITRAQ proteomics reveals the regulatory response to Magnaportheoryzae in durable resistant vs. susceptible rice genotypes. PLoS ONE 15:1-20

Malencic DJ, Vasic D, Popovic M, Devic D (2004) Antioxidant systems in sunflower as affected by oxalic acid. Biol Plant 48:243-247

Malinovsky FG, Fangel JU, Willats WG (2014) The role of the cell wall in plant immunity. Front Plant Sci 5:178

Marcel S, Sawers R, Oakeley E, Angliker H, Paszkowski U (2010) Tissue-adapted invasion strategies of the rice blast fungus Magnaportheoryzae. Plant Cell 22:3177-3187

Masisi K, Beta T, Moghadasian MH (2016) Antioxidant properties of diverse cereal grains: a review onin vitro and in vivo studies. Food Chem 196:90-97

Meng X, Zhang S (2013) MAPK Cascades in plant disease resistance signaling vol 51: pp. 245-266. https://doi.org/10.1146/AnnurevPhyto-082712-102314

Meo SD, Reed TT, Venditti P, Victor VM (2016) Harmful and beneficial role of ROS. Oxid Med Cell Longev 2016:1-3

Meyer RC, Steinfath M, Lisec J, Becher M, Witucka-Wall H, Torjek O, Fiehn O, Eckardt A, Willmitzer L, Selbig J, Altmann T (2007) The metabolic signature related to high plant growth rate in Arabidopsis thaliana. Proc Natl Acad Sci U S A 104(11):4759-4764

Miller GAD et al (2010) Reactive oxygen species homeostasis and signaling duringdrought and salinity stresses. Plant Cell Environ $33: 453-467$

Mishra VK, Biswas SK, Rajik M (2011) Biochemical mechanism of resistance to Alternaria blight by different varieties of wheat. Int J Plant Pathol 2:72-80

Mittler R (2017) ROS are good. Trends Plant Sci 22:11-19

Moerschbacher B, Mendgen K (2012) Structural aspect of plant defense. In: Slusarenko AJ, Fraser RSS, van Loon LC (eds) Mechanisms of Resistance to Plant Diseases. Springer Science \& Business Media, Berlin

Mohammad RH, Bahman K (2018) Changes in some antioxidant enzymes activities and carotenoid content in potato plants infected by Rhizoctonia solani treated with salicylic acid. Arch Phytopathol Pflanzenschutz 51:649-661 
Nandakumar M, Malathi P, Sundar AR, Viswanathan R (2021) Hostpathogen interaction in sugarcane and red rot pathogen: exploring expression of phytoalexin biosynthesis pathway genes. Indian Phytopathol 74:529-535

Nawrocka J, Małolepsza U (2013) Diversity in plant systemic resistance induced by Trichoderma. Biol Control 67:149-156

Ngou BPM, Ahn HK, Ding P, Jones JDG (2021) Mutual potentiation of plant immunity by cell-surface and intracellular receptors. Nature 592(7852):110-115

Nicholson RL, Hammerschmidt R (1992) Phenolic compounds and their role in disease resistance. Annu Rev Phytopathol 30:369-389

Nida H, Lee S, Li Y et al (2021) Transcriptome analysis of early stages of sorghum grain mold disease reveals defense regulators and metabolic pathways associated with resistance. BMC Genomics 22:295

Norvienyeku J, Lin L, Waheed A et al (2020) Bayogenin 3-Ocellobioside confers non cultivar-specific defense against the rice blast fungus Pyriculariaoryzae. Plant Biotechnol J. https://doi. org/10.1111/pbi.13488

Nose NP, Dalcin MS, Bruna Dias L, Toloy RS et al (2022) Noni essential oil associated with adjuvants in the production of phytoalexins and in the control of soybean anthracnosis. J Med Plant Res 16(1):1-10

Paznocht L, Kotikova Z, Sulc M, Lachman J, Orsak M, Eliasova M, Martinek P (2017) Free and esterified carotenoids in pigmented wheat, tritordeum and barley grains. Food Chem 240:670-678

Petrov V, Hille J, Mueller-roeber B, Gechev TS (2015) ROSmediated abiotic stress-induced programmed cell death in plants. Front Plant Sci 6:1-16

Poprac P, Jomova K, Simunkova M, Kollar V, Rhodes CJ, Valko M (2017) Targeting free radicals in oxidative stress-related human diseases. Trends Pharma Sci 38:592-607

Purwantisari S, Priyatmojo A, Sancayaningsih RP, Kasiamdari RS, Budihardjo K (2020) Lignification on potatoes by application of trichoderma viride. In: IOP conference series earth environment science vol. 518 pp. 012075

Raj S, Niranjan BR, Sarosh., and Shetty H.S. (2006) Induction and accumulation of polyphenol oxidase activities as implicated in development of resistance against pearl millet downy mildew disease. Funct Plant Biol 33(6):563

Razzaq A, Shamsi S, Ali A, Ali Q, Sajjad M, Malik A, Ashraf M (2019) Microbial proteases applications. Front Bioeng Biotechnol 7:110

Sabella E, Luvisi A, Aprile A, Negro C, Vergine M, Nicoli F, Miceli A, De Bellis L (2018) Xylella fastidiosa induces differential expression of lignification related-genes and lignin accumulation in tolerant olive trees cv. Leccino. J Plant Physiol 220:60-68

Sahni S, Prasad BD (2020) Management of collar rot disease using vermicompost and a PGPR strain Pseudomonas sp. and their effect on defense-related enzymes in chickpea. Indian Phytopathol 73:301-311

Salas-Marina MA et al (2011) Colonization of Arabidopsis roots by Trichoderma atroviridepromotes growth and enhances systemic disease resistance through jasmonic acid/ethylene and salicylic acid pathways. Eur J Plant Pathol. 131:15-26

Samota MK, Sasi M, Awana M, Yadav OP, Amitha MSV, Tyagi A, Kumar S, Singh A (2017) Elicitor-induced biochemical and molecular manifestations to improve drought tolerance in rice (Oryza sativa L.) through seed-priming. Front Plant Sci 8:934

Sana TR, Fischer S, Wohlgemuth G, Katrekar A, Jung KH, Ronald PC, Fiehn O (2010) Metabolomic and transcriptomic analysis of the rice response to the bacterial blight pathogen Xanthomonas oryzaepv oryzae. Metabolomics 6(3):451-465

Sandalio LM, Peláez-Vico MA, Molina-Moya E, Romero-Puertas MC (2021) Peroxisomes as redox-signaling nodes in intracellular communication and stress responses. Plant Physiol 186(1):22-35. https://doi.org/10.1093/plphys/kiab060

Santen K, Marttila S, Liljeroth E, Bryngelsson T (2005) Immunocytochemical localization pf the pathogenesis-related PR-1 protein in barley leaves after infection by Bipolarissorokiniana. Physiol Mol Plant Pathol 66:45-54

Schmelz EA, Kaplan F, Huffaker A, Dafoe NJ, Vaughan MM, Ni X, Rocca JR, Alborn HT, Teal PE (2011) Identity, regulation, and activity of inducible diterpenoid phytoalexins in maize. Proc Natl Acad Sci 108(13):5455-60

Scossa F, Brotman Y, de Abreu E, Lima F, Willmitzer L, Nikoloski Z, Tohge T, Fernie AR (2016) Genomics-based strategies for the use of natural variation in the improvement of crop metabolism. Plant Sci 242:47-64

Scott-Craig JS, Kerby KB, Stein BD, Somerville SC (1995) Expression of an extracellular peroxidase that is induced in barley (Hordeum vulgare) by the powdery mildew pathogen (Erysiphe graminis f. sp. hordei). Physiol Mol Plant Pathol 47:407-418

Sels J, Mathys I, De Coninck BMA, Cammue BPA, De BFC (2008) Plant pathogenesis- related (PR) proteins: a focus on PR peptides. Plant Physiol Biochem 46:941-950

Seybold H, Demetrowitsch TJ, Hassani MA, Szymczak S, Reim E, Haueisen J, Lubbers L, Ruhlemann M, Franke A, Schwarz K, Stukenbrock EH (2020) A fungal pathogen induces systemic susceptibility and systemic shifts in wheat metabolome and microbiome composition. Nat Commun 11(1):1910

Shahidi F, Yeo J (2016) Insoluble-bound phenolics in food. Molecules 21:1-22

Shan T, Rong W, Xu H, Du L, Liu X, Zhang Z (2016) The wheat R2R3-MYB transcription factor TaRIM1 participates in resistance response against the pathogen Rhizoctoniacerealis infection through regulating defense genes. Sci Rep 6(1):28777

Sharma P, Jha AB, Dubey RS, Pessaraki M (2012) Reactive oxygen species, oxidative damage and antioxidative defense mechanism in plants under stressful conditions. J Bot 3:1-26

Shavit R, Batyrshina ZS, Dotan N, Tzin V (2018) Cereal aphids differently affect benzoxazinoid levels in durum wheat. PLoS ONE 13(12):e0208103

Singla P, Bhardwaj RD, Kaur S, Kaur J (2019) Antioxidant potential of barley genotypes inoculated with five pathotypes of Puccinia striiformis f Sp Hordei. Physiol Mol Biol Plants 25:145-157

Singla P, Bhardwaj RD, Kaur S, Kaur J (2020) Stripe rust induced defense mechanisms in the leaves of contrasting barley genotypes (Hordeum vulgare L.) at the seedling stage. Protoplasma 257(1):169-181

Song C, Wang X, Yang J, Kuang Y, Wang Y, Yang S, Qin J, Guo L (2021) Antifungal biphenyl derivatives from sorbus pohuashanensis leaves infected by alternaria tenuissi and their effect against crop pathogens. Chem Biodivers. 18(5):e2100079

Stangarlin JR, Pascholati SF (2000) Activity of ribulose-1, 5-bisphosphate carboxylase-oxygenase (Rubisco), chlorophyllase, $\beta-1$, 3 -glucanase and chitinase and chlorophyll content in bean cultivars (Phaseolus vulgaris) infected with uromycesappendiculatus. SummmaPhytopathol 26:34-42

Suarez V, Staehelin C, Arango R, Holtorf H, Hofsteenge J, Meins JF (2001) Substrate specificity and antifungal activity of recombinant tobacco class I chitinases. Plant Mol Biol 45:609-618

Suharti WS, Nose A, Zheng SH (2016) Metabolite profiling of sheath blight disease resistance in rice:in the case of positive ion mode analysis by CE/TOF-MS. Plant Prod Sci 19:1-12

Takahashi Y, Berberich T, Miyazaki A, Seo S, Ohashi Y, Kusano T (2004) Spermine signaling in tobacco: activation of mitogenactivated protein kinases by spermine is mediated through mitochondrial dysfunction. Plant J 36:820-9 
Tamaoki D, Seo S, Yamada S, Kano A, Miyamoto A, Shishido H, Miyoshi S, Taniguchi S, Akimitsu K, Gomi K (2013) Jasmonic acid and salicylic acid activate a common defense system in rice. Plant Signal Behav. 8:e24260

Tekbas OF, Ogur R, Korkmaz A, Kilic A, Reiter RJ (2008) Melatonin as an antibiotic: new insights into the actions of this ubiquitous molecule. J Pineal Res 44(2):222-226

Torun H (2019) Time-course analysis of salicylic acid effects on ROS regulation and antioxidant defense in roots of hulled and hulless barley under combind stress of drought, heat and salinity. Physiol Plant 165:169-182

Tsuda K, Somssich IE (2015) Transcriptional networks in plant immunity. New Phytol 206(3):932-947

Turra D, ElGhalid M, Rossi F, DiPietro A (2015) Fungal pathogen uses sex pheromone receptor for chemotropic sensing of host plant signals. Nat 527:521-524

Ube N, Katsuyama Y, Kariya K, Tebayashi SI, Sue M, Tohnooka T, Ueno K, Taketa S, Ishihara A (2021) Identification of methoxylchalcones produced in response to $\mathrm{CuCl} 2$ treatment and pathogen infection in barley. Phytochemistry 184:112650

Vance CP, Kirk TK, Sherwood RT (1980) Lignification as a mechanism of disease resistance. Annu Rev Phytopathol 18:259-288

Vanitha S, Niranjana S, Mortensen C, Umesha S (2009) Bacterial wilt of tomato in Karnataka and its management by Pseudomonas fluorescens. Bio Control 54:685-695

Voigt CA (2014) Callose-mediated resistance to pathogenic intruders in plant defense-related papillae. Front Plant Sci 5:168

Wang T, Li Q, Bi K (2018) Bioactive flavonoids in medicinal plants: structure, activity and biological fate. Asian J Pharma Sci 13:12-23

Wen W, Liu H, Zhou Y, Jin M, Yang N, Li D, Luo J, Xiao Y, Pan Q, Tohge T, Fernie AR, Yan J (2016) Combining quantitative genetics approaches with regulatory network analysis to dissect the complex metabolism of the maize kernel. Plant Physiol 170:136-146

Windisch S, Walter A, Moradtalab N, Walker F, Hoglinger B, ElHasan A, Ludewig U, Neumann G, Grosch R (2021) Role of benzoic acid and lettucenin a in the defense response of lettuce against soil-borne pathogens. Plants (Basel) 10(11):2336

Xie Y, Hou W, Song X, Yu Y, Huang J, Sun X, Kang R, Tang D (2016) Ferroptosis: process and function. Cell Death Diff 23:369-379
Yamasaki H, Cohen MF (2006) NO signal at the crossroads: polyamine induced nitric oxide synthesis in plants. Trend Plant Sci 11:522-524

Yang Q, Trinh HX, Imai S, Ishihara A, Zhang L, Nakayashiki H, Tosa Y, Mayama S (2004) Analysis of the involvement of hydroxyanthranilate hydroxyl cinnamoyl transferase and caffeoyl-CoA 3-O-methyltransferase in phytoalexin biosynthesis in oat. Mol Plant Microbe Interact 17(1):81-89

You X, Fang H, Wang R, Wang G-L, Ning Y (2020) Phenylalanine ammonia lyases mediate broad-spectrum resistance to pathogens and insect pests in plants. Sci Bull 65(17):1425-1427. https:// doi.org/10.1016/j.scib.2020.05.014

Young AJ, Lowe GL (2018) Carotenoids-antioxidant properties. Antioxid 7:1-4

Zaynab M, Fatima M, Sharif Y, Zafar MH, Ali H, Khan KA (2019) Role of primary metabolites in plant defense against pathogens. Microb Pathog 137:103728

Zhang H, Huang Q, Yi L, Song X, Li L, Deng G, Liang J, Chen F, Yu M, Long H (2021) PAL-mediated SA biosynthesis pathway contributes to nematode resistance in wheat. Plant $\mathbf{J}$ 107(3):698-712. https://doi.org/10.1111/tpj.15316

Zhao P, Gu S, Han C, Lu Y, Ma C, Tian J, Bi J, Deng Z, Wang Q, Xu $Q$ (2021) Targeted and untargeted metabolomics profiling of wheat reveals amino acids increase resistance to fusarium head blight. Front Plant Sci 12:762605-762605

Zhou X, Liu Z (2022) Unlocking plant metabolic diversity: a (pan)genomic view. Plant Commun. https://doi.org/10.1016/j.xplc. 2022.100300

Zhou S, Zhang YK, Kremling KA, Ding Y, Bennett JS, Bae JS, Kim DK, Ackerman HH, Kolomiets MV, Schmelz EA, Schroeder FC, Buckler ES, Jander G (2019) Ethylene signaling regulates natural variation in the abundance of antifungal acetylated diferuloylsucroses and Fusarium graminearum resistance in maize seedling roots. New Phytol 221(4):2096-2111

Zhu Z, Lee B (2015) Friends or foes: new insights in jasmonate and ethylene co-actions. Plant Cell Physiol 56:414-420

Zou C, Wang P, Xu Y (2016) Bulked sample analysis in genetics, genomics and crop improvement. Plant Biotechnol J 14(10):1941-1955

Publisher's Note Springer Nature remains neutral with regard to jurisdictional claims in published maps and institutional affiliations. 